\title{
The Dietary Importance of Kelp-Derived Detritus to Pelagic and Benthic Consumers along the West Coast of Vancouver Island, Canada
}

\author{
Brock Christopher Ramshaw ${ }^{1,2 *}$, Evgeny Alexandrovich Pakhomov ${ }^{2,3,4}$ \\ ${ }^{1}$ 101-108 Esplanade W, North Vancouver, Canada \\ ${ }^{2}$ Department of Earth, Ocean and Atmospheric Sciences, University of British Columbia, Vancouver, Canada \\ ${ }^{3}$ Institute for the Oceans and Fisheries, University of British Columbia, Vancouver, Canada \\ ${ }^{4}$ Hakai Institute, Campbell River, Canada \\ Email: ^brockramshaw@gmail.com
}

How to cite this paper: Ramshaw, B.C. and Pakhomov, E.A. (2021) The Dietary Importance of Kelp-Derived Detritus to Pelagic and Benthic Consumers along the West Coast of Vancouver Island, Canada. Open Journal of Marine Science, 11, 187-213.

https://doi.org/10.4236/ojms.2021.114012

Received: August 16, 2021

Accepted: October 9, 2021

Published: October 12, 2021

Copyright $\odot 2021$ by author(s) and Scientific Research Publishing Inc. This work is licensed under the Creative Commons Attribution International License (CC BY 4.0).

http://creativecommons.org/licenses/by/4.0/

\begin{abstract}
Stable isotope analysis was used to determine the relative dietary importance of kelp-derived detritus to plankton and benthic organisms along a gradient of kelp abundance driven by recovering sea otter populations along the west coast of Vancouver Island (WCVI), Canada. The study used region-specific kelp isotope values $\left(\delta^{13} \mathrm{C}\right.$ and $\left.\delta^{15} \mathrm{~N}\right)$ and season-specific phytoplankton isotope values to model dietary contributions of kelp-derived detritus (KDD). In general, KDD contributions were moderate to high in most plankton size fractions during the summer and decreased during the winter, particularly in the kelp sparse region. Hypothesized regional and spatial (distance from the coast) differences in kelp detritus contributions to zooplankton were not evident. Modeled estimates of the KDD contribution to benthic invertebrates were high $(>40 \%)$ and independent of the organism size, among regions and between seasons, with the exception of Astraea gibberosa in the kelp abundant region. Local oceanography, natural kelp isotope signature variation, and significant overlap between kelps' and blooming phytoplankton isotope values led to a large uncertainty in the assessed KDD contributions in benthic organisms. These results highlighted the importance of the KDD as a widespread and stable year-round food source in coastal kelp populated regions.
\end{abstract}

\section{Keywords}

Kelp-Derived Detritus, Primary Production, Stable Isotopes, Vancouver Island, Particulate Organic Matter, Kelp, Benthic Organisms, Primary 


\section{Introduction}

Identifying drivers of nearshore ecosystem productivity, diversity and stability contribute to our understanding of food web, community and ecosystem ecology. Detritus, as an autochthonous and allochthonous subsidy, is an important bottom-up driver of trophic structure and food web dynamics by influencing energy, carbon and nutrient budgets [1] [2]. Generally, the biomass of pelagic and benthic organisms is a function of local water column productivity [2]. However, the flow of subsidies across habitats can create diverse and subsidized food webs where local productivity is low [2]. The dispersal and concentration of subsidies can be affected by local surface and bottom currents [3], regional productivity, and the ratio of habitat perimeter to area [4].

Coastal marine consumers feed directly, or indirectly, on kelp- and/or phytoplankton-derived organic matter. Kelps (Phaeophycea: Order Laminariales) are large fleshy macroalgae that occupy low intertidal and shallow subtidal rocky reef habitats of temperate coastal marine ecosystems [5]. Kelps contribute substantially to nearshore primary productivity [6], with estimates as high as $3000 \mathrm{~g}$ $\mathrm{C} \mathrm{m}^{-2} \cdot \mathrm{yr}^{-1}$ [6] [7] [8] [9]. In British Columbia, bull kelp (Nereocystis luetkeana) sporophytes are able to assimilate $1400 \mathrm{~g} \mathrm{C} \mathrm{m}^{-2}$ during summer [10] and giant kelp (Macrocystis pyrifera) productivity estimates range from 460 to $1300 \mathrm{~g} \mathrm{C}$ $\mathrm{m}^{-2} \cdot \mathrm{yr}^{-1}$ [6] [7] [11]. Most of the ocean-based photosynthesis occurs along coastal margins, which occupy only $0.1 \%$ of the total ocean area but average phytoplankton productivity in upwelling regions ranges from 200 to $973 \mathrm{~g} \mathrm{C} \mathrm{m}^{-2} \cdot \mathrm{yr}^{-1}$ [12] [13]. Phytoplankton concentrations along the west coast of Vancouver Island (WCVI) reach a maximum during late spring to mid-summer when solar radiation is high and nutrients are readily available from winter mixing of the water column and upwelling [14] [15]. The relative contribution to particulate organic matter (POM) of these two main primary production sources (phytoplankton and macrophytes) can vary spatially and temporally [16] [17] [18] [19]. However, the year-round presence of kelp-derived detritus (KDD) could be important in the food web dynamics, and system stability, and have considerable effects on trophic structure and biodiversity [20].

With over $80 \%$ of the annual kelp production dispersed to the surrounding shallow and deep-water ecosystems through both KDD and dissolved organic matter (DOM) [21] [22] [23] [24], kelp production is important to kelp associated communities [16] [25] [26]. It may also be transported great distances from source populations as suspended POM [17] [18] [27]. Kelp-derived detritus (KDD) can be detected at great depths [3] [24] and is known to subsidize island and nearshore communities [4] [16] [28]. However, some studies have called into question the suitability of kelp as a food source because of high C:N 
ratios [29], high concentrations of secondary metabolites [30], and structural rigidness [31]. Bacterial degradation of KDD can lower C:N ratios and secondary metabolite content [32], thereby increasing its nutritional quality. Relative to phytoplankton, kelp-derived carbon can contribute similarly or more to the diets of nearshore benthic invertebrate filter-feeders with estimates as high as $90 \%$ [16] [33] [34]. More importantly, KDD can increase consumer growth rates by 2 to 5-fold, relative to pure phytoplankton diets [33], and may have important consequences for population dynamics and ecosystem productivity [20].

Carbon and nitrogen stable isotope analysis is a commonly used and powerful tool in food web ecology that quantifies the incorporation of potential food sources (e.g. phytoplankton and kelp) into consumers and estimates the average trophic level of consumers [35] [36]. Variability and uncertainty in source isotope values complicate this method and have possibly led to the overestimation of KDD contribution to organisms in previous studies [37]. In marine ecosystems, $\delta^{13} \mathrm{C}$ values typically increase by $0 \%$ to $1 \%$ per trophic level [35] [36] [38] [39]. Changes in $\delta^{15} \mathrm{~N}$ values with each trophic level transfer vary with tissue type [40] and feeding mode [39]. The average increase of $\delta^{15} \mathrm{~N}$ values with trophic level ranges from $1.4 \%$ for consumers of invertebrates [39] to $4 \%$ o for filter-feeders [34].

The research aims of this study were twofold: first, to assess the KDD contributions to the tissues of plankton and benthic invertebrates near and offshore in a $\sim 20$-fold kelp productivity gradient resulting from sea otter population recovery along the WCVI; second, to investigate seasonal variability in the KDD contributions to pelagic and benthic invertebrates along the WCVI.

\section{Materials and Methods}

\subsection{Study System}

The research was conducted along the west coast of Vancouver Island (WCVI), British Columbia, Canada (Figure 1), situated at the northern end of the California Current Large Marine Ecosystem [41]. Complex oceanographic processes characterize this coastline. Seawater over the outer shelf, demarcated by a $100 \mathrm{~m}$ isobath, flows pole-ward during the winter but changes direction from northwestward to south-eastward during the spring with the seasonal onset of the coastal upwelling, and reverses again in the fall [42] [43]. The buoyancy driven Vancouver Island Coastal Current (VICC) dominates the flow over the inner ( $<100 \mathrm{~m}$ depth) continental shelf. This current flow pole-ward year-round but can be reversed in the upper $50 \mathrm{~m}$ by strong northwest winds that occur during upwelling favouring conditions in summer or during cold outflow conditions during winter [44].

Sea otters are voracious consumers and exert strong top-down control on many benthic invertebrates, most notably sea urchins of Strongylocentrotus genus. In the absence of sea otters, hyper-abundant urchin populations devastate macroalgal populations resulting in widespread urchin "barrens" [45]. In the 


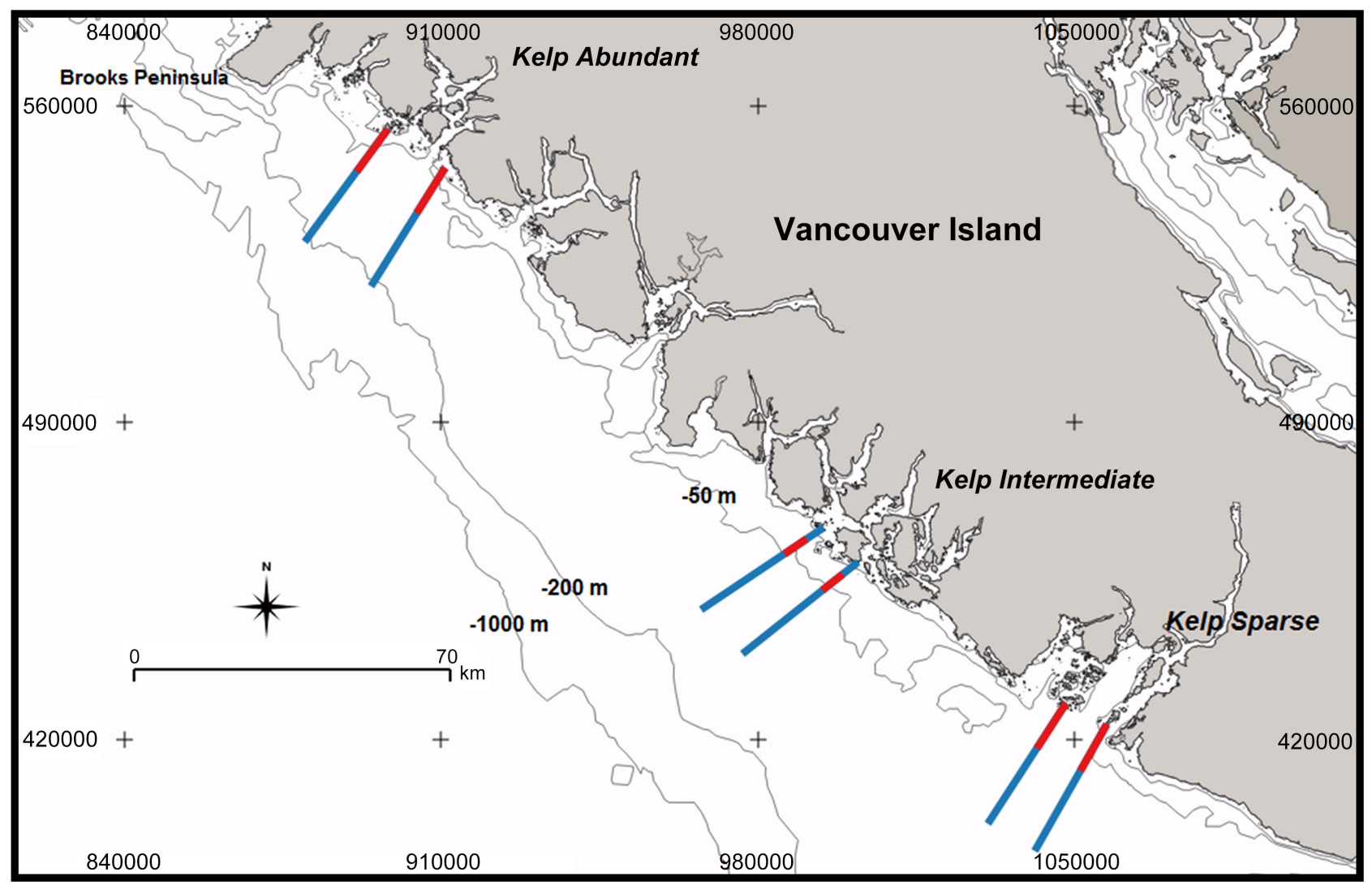

Figure 1. Sampling regions along the west coast of Vancouver Island (WCVI). The red lines represent summer transects $(0-30$ $\mathrm{km}$ ). During winter, sampling was only to $10 \mathrm{~km}$ from the kelp forest in the kelp abundant and kelp sparse regions, and only at 4 and $8 \mathrm{~km}$ in the kelp intermediate region. Sampling transects indicated by KA-T1, KA-T2, etc.

presence of sea otters, sea urchins are heavily preyed upon which is followed by re-establishment of extensive kelp forests that support diverse and productive ecosystems [5] [46] [47]. As a result of the North Pacific maritime fur trade, sea otters were extirpated from the coast of British Columbia by 1929 [48]. However, between 1969 and 1972 eighty-nine animals were reintroduced to the northwest coast of Vancouver Island from western Alaska [49]. This population has increased rapidly and expanded north- and southwards along the WCVI [50] [51]. At the time of sampling, sea otters were distributed from the northern tip of Vancouver Island southward to an area just south of Clayoquot Sound (Figure 1) and have dramatically increased kelp populations along this coastline [52] [53].

\subsection{Experimental Design}

Three research cruises were conducted off the WCVI between July 2009 and July 2010. The study region included three large sounds that were characterized by large differences in kelp biomass corresponding to the sea otter occupation time [52] [53]. A "space-for-time substitution" approach [54] was used to take advantage of sea otter reintroduction and range expansion along the WCVI. Kyuquot Sound (Figure 1), in the north (nearest to where sea otters were first rein- 
troduced and re-established), has the highest kelp abundance and is hereafter referred to as "kelp abundant". Clayoquot Sound is hereafter referred to as "kelp intermediate", and Barkley Sound, with the lowest kelp abundance, is referred to as "kelp sparse" [27]. The kelp abundant and kelp sparse regions were approximately $170 \mathrm{~km}$ apart. Two transects located 10 to $12 \mathrm{~km}$ apart originated within kelp forests at the mouth of each sound and ran perpendicular to the coastline with sampling at $0,0.5,1,2,4,10$ and $30 \mathrm{~km}$ from the kelp forest. In the "kelp sparse" and "kelp abundant" regions summer sampling occurred between July 18th and 23rd, 2009; summer sampling off the kelp intermediate region was conducted between July 27 th and July 28 th, 2010 . Winter sampling only took place off the kelp abundant and kelp sparse regions between January 23rd and 31st, 2010 due to inclement weather. It was assumed that sampled organisms were feeding on KDD produced within their respective sounds.

Regional kelp and phytoplankton isotope value estimates $\left(\delta^{13} \mathrm{C}\right.$ and $\left.\delta^{15} \mathrm{~N}\right)$, see Table 1 and [27] were used in a Bayesian mixing model (MixSIR) to quantify the percent relative contribution of kelp-versus phytoplankton-derived detritus to plankton and benthic invertebrates. It was predicted that during summer and winter nearshore and offshore organisms in the high kelp productivity, i.e. kelp abundant, region would have higher proportions of KDD, in comparison to a region where sea otters are absent and kelp productivity is low.

Size-fractionated plankton stable isotopes

At each station, surface size-fractionated plankton: 63 - $125 \mu \mathrm{m}, 125$ - $250 \mu \mathrm{m}$, $250-500 \mu \mathrm{m}$, and $500-2000 \mu \mathrm{m}$ were collected. One surface tow was performed at each distance by towing a $63 \mu \mathrm{m}$ net horizontally for 5 to 10 minutes at approximately 1 knot. All samples were size-fractionated and frozen in a $-20^{\circ} \mathrm{C}$ freezer at sea. Some samples did not have all size-fractions analyzed due to lack of sample volume.

Table 1. Summer and winter phytoplankton $\delta^{13} \mathrm{C}$ and $\delta^{15} \mathrm{~N}$ values $(\% \pm \pm \mathrm{SD})$ used in the MixSIR isotope mixing model program for zooplankton and benthic organisms.

\begin{tabular}{|c|c|c|c|c|c|}
\hline \multirow[b]{2}{*}{ POM size fraction } & \multirow[b]{2}{*}{ Phytoplankton type } & \multicolumn{2}{|c|}{ Summer } & \multicolumn{2}{|c|}{ Winter } \\
\hline & & $\begin{array}{c}\text { Mean } \delta^{13} \mathrm{C} \pm \mathrm{SD} \\
(\% 0)\end{array}$ & $\begin{array}{c}\text { Mean } \delta^{15} \mathrm{~N} \pm \mathrm{SD} \\
(\% \mathrm{o})\end{array}$ & $\begin{array}{c}\text { Mean } \delta^{13} \mathrm{C} \pm \mathrm{SD} \\
(\%)\end{array}$ & $\begin{array}{c}\text { Mean } \delta^{15} \mathrm{~N} \pm S D \\
(\% 0)\end{array}$ \\
\hline \multirow[b]{2}{*}{$20-63 \mu \mathrm{m}$ POM } & Blooming phytoplankton $20-63 \mu \mathrm{m}$ & $\begin{array}{l}-19.03 \pm 0.87 \\
\quad(\mathrm{n}=22)\end{array}$ & $\begin{array}{l}6.83 \pm 0.63 \\
(\mathrm{n}=22)\end{array}$ & No bloom & No bloom \\
\hline & Non - blooming phytoplankton $20-63 \mu \mathrm{m}$ & $\begin{array}{c}-21.41 \pm 1.48 \\
(\mathrm{n}=10)\end{array}$ & $\begin{array}{c}5.59 \pm 1.21 \\
(\mathrm{n}=10)\end{array}$ & $\begin{array}{c}-22.07 \pm 1.37 \\
(\mathrm{n}=19)\end{array}$ & $\begin{array}{c}6.27 \pm 0.97 \\
(\mathrm{n}=19)\end{array}$ \\
\hline \multirow[b]{2}{*}{$0.7-20 \mu \mathrm{m}$ POM } & Blooming phytoplankton $0.7-20 \mu \mathrm{m}$ & $\begin{array}{c}-21.49 \pm 0.67 \\
(\mathrm{n}=22)\end{array}$ & $\begin{array}{l}6.66 \pm 1.29 \\
(\mathrm{n}=22)\end{array}$ & No bloom & No bloom \\
\hline & Non - blooming phytoplankton 0.7 - $20 \mu \mathrm{m}$ & $\begin{array}{c}-22.37 \pm 1.10 \\
(\mathrm{n}=10)\end{array}$ & $\begin{array}{c}6.34 \pm 1.03 \\
(\mathrm{n}=10)\end{array}$ & $\begin{array}{c}-23.84 \pm 0.68 \\
(\mathrm{n}=20)\end{array}$ & $\begin{array}{c}6.87 \pm 0.91 \\
(\mathrm{n}=20)\end{array}$ \\
\hline $\begin{array}{l}\text { Oceanic Total } \\
\operatorname{POM}(>0.7 \mu \mathrm{m})\end{array}$ & $\begin{array}{l}\text { Oceanic phytoplankton }(37,48 \text { and } 118 \mathrm{~km} \\
\text { offshore-used for summer and winter) }\end{array}$ & \multicolumn{2}{|c|}{$\begin{array}{c}-25.50 \pm 1.38 \\
(\mathrm{n}=3)\end{array}$} & \multicolumn{2}{|c|}{$\begin{array}{l}3.83 \pm 1.66 \\
(\mathrm{n}=3)\end{array}$} \\
\hline
\end{tabular}


In the laboratory, all samples were thawed, randomly sub-sampled in triplicates to identify and enumerate major plankton groups within each size fraction. Samples were then dried in a Fisher Scientific oven at $50^{\circ} \mathrm{C}$ for at least 24 hours, ground into a powder and packaged into $5 \times 8 \mathrm{~mm}$ tin capsules for stable isotope analysis. KDD was visible microscopically, especially in the $63-125 \mu \mathrm{m}$ and $125-250 \mu \mathrm{m}$ size fractions, but was difficult to quantify and is therefore not included.

\subsection{Benthic Organism Stable Isotopes}

Benthic dredging was performed with a $60 \mathrm{~cm}$ by $30 \mathrm{~cm}$ dredge towed along the bottom for 5 to 10 minutes at approximate speed of 1.5 to 2 knots. This was done at all stations except within the kelp forests $(0 \mathrm{~km})$ and at some $30 \mathrm{~km}$ stations that were too deep to sample. Samples were immediately frozen in a $-20^{\circ} \mathrm{C}$ freezer. In the laboratory, benthic samples were thawed, identified to lowest possible taxonomic level, and rinsed with distilled water. Red turban snails ( $A s$ traea gibberosa), hermit crabs (Infraorder Anomura) and pink scallops (Chlamys spp.) were the only organisms consistently abundant enough to include in analyses. The tissues of these common species/groups (muscle or, whole body minus the shell) were dried for at least 24 hours at $50^{\circ} \mathrm{C}$. Dried samples were ground with a mortar and pestle or digital amalgamator, and packaged in tin capsules for carbon and nitrogen stable isotope analysis. Benthic samples from within the kelp forests were collected using SCUBA during the summer of 2009.

To test for possible acidification effects on isotope values, 7 hermit crabs were acidified with $0.1 \mathrm{M} \mathrm{HCl}$ from an eye-dropper, while the remaining 61 remained untreated. The number of drops varied from 5 to 17 and was applied until $\mathrm{CO}_{2}$ gas stopped being released, i.e. stopped bubbling [55]. The sample was then re-dried without rinsing to minimize the loss of DOM and ground into a powder again [56] [57].

To test for possible lipid extraction (i.e. defatting) effects on red turban snail stable isotope values, five whole snails were split in half and one half was defatted, and the other remained untreated, following the method of Bligh and Dyer [58] and then lightly rinsed with distilled water on $0.7 \mu \mathrm{m}$ Whatman GF/F filters with light suction. Samples were re-dried and ground into a powder. Additionally, C:N ratios were used to check for excess lipids in both cases.

All isotope analyses were conducted at IsoEnvironmental in Grahamstown, South Africa. Abundances of naturally occurring carbon and nitrogen stable isotopes were determined on either a Europa Scientific Integra IRMS or Europa Scientific 20-20 IRMS linked to an ANCA SL Elemental Analyser. Beet sugar and ammonium sulphate were used as internal standards, calibrated against several International Atomic Energy Agency (IAEA) reference materials. Results are expressed in the standard delta notation, as $X=\left[\left(R_{\text {sample }} / R_{\text {standard }}\right)-1\right] \times 1000$, where $X=$ element in question and $R=$ ratio of the heavy over the light isotope. 
Repeated analyses of homogeneous material yielded a $\delta^{13} \mathrm{C}$ standard deviation of $0.11 \%$ and a $\delta^{15} \mathrm{~N}$ standard deviation of $0.16 \%$.

\subsection{Data Analyses}

Size-fractionated plankton: Linear regression was used to assess the relationship between distance from the kelp forest and plankton $\delta^{13} \mathrm{C}$ values.

Benthic organisms: Where assumptions were met, paired $\mathrm{t}$-tests were used to test for effects of acidification and lipid extraction of benthic organisms. In cases of non-normality or heterogeneous variance, Wilcoxon Matched pairs tests were used. Linear regression was used to assess relationships between stable isotope values and organism size (length or width). All statistical analyses were performed in $\mathrm{R}$ [59].

MixSIR: We used the isotope mixing model program MixSIR (version 1.0, [60]) to determine percent KDD contribution to plankton and benthic organisms. MixSIR is a graphical user interface that performs Bayesian analysis of stable isotope mixing models using Hilborn sampling-importance-resampling (SIR) algorithm [61]. The benefits of a Bayesian approach to stable isotope mixing models include: 1) accounting for uncertainty in source stable isotope values, 2) accounting for uncertainty in the estimates of source contributions as there is underlying uncertainty in the mixture and source isotope values, 3) determining a unique solution when more than two sources are present [62] [63]. Outputs of the program include a median percent contribution of all sources included and their respective $95 \%$ confidence intervals. The degree of overlap between confidence intervals defines the probability that two estimates are the same. Source $\delta^{13} \mathrm{C}$ fractionation and fractionation standard deviations were set to $0 \%$ for summer and winter plankton. Source $\delta^{15} \mathrm{~N}$ fractionation and fractionation standard deviations were set to $1.47 \%$ o $\pm .39 \%$, while for winter it was $2.32 \%$ \pm $0.46 \%$. For other consumers the values used were $0.5 \%$ o $\pm 0.13 \%$ or $\delta^{13} \mathrm{C}$ and $2.2 \%$ $\pm 0.3 \%$ (for primary consumers), $2.13 \%$ o $\pm 0.18 \%$ o (for omnivores and detritivores) and 3.3\%o $\pm 0.26 \%$ (for higher consumers) for $\delta^{15} \mathrm{~N}$ [64]. These values will be justified in the "Results" section.

\section{Results}

\subsection{Surface Plankton Carbon Stable Isotopes}

Summer: Phytoplankton species composed the largest proportional abundance of the 63 - $125 \mu \mathrm{m}$ plankton (0.85) surface tows and 0.35 of the 125 - 250 $\mu \mathrm{m}$ fraction (Figure 2(A)). Different growth stages of copepods constituted the largest proportional abundance of plankton $>125 \mu \mathrm{m}$ with proportions of 0.39 , 0.45 , and 0.47 for the $125-250,250-500$ and $500-2000 \mu \mathrm{m}$ size fractions, respectively (Figure $2(\mathrm{~A})$ ). Cladocerans made the second largest contributions to both the $250-500 \mu \mathrm{m}(0.35)$ and the $500-2000 \mu \mathrm{m}$ fractions (0.17). Decapods were the third largest contributor to the $500-2000 \mu \mathrm{m}$ plankton (0.14).

Among regions differences were not significant in surface plankton $\delta^{13} \mathrm{C}$ values 


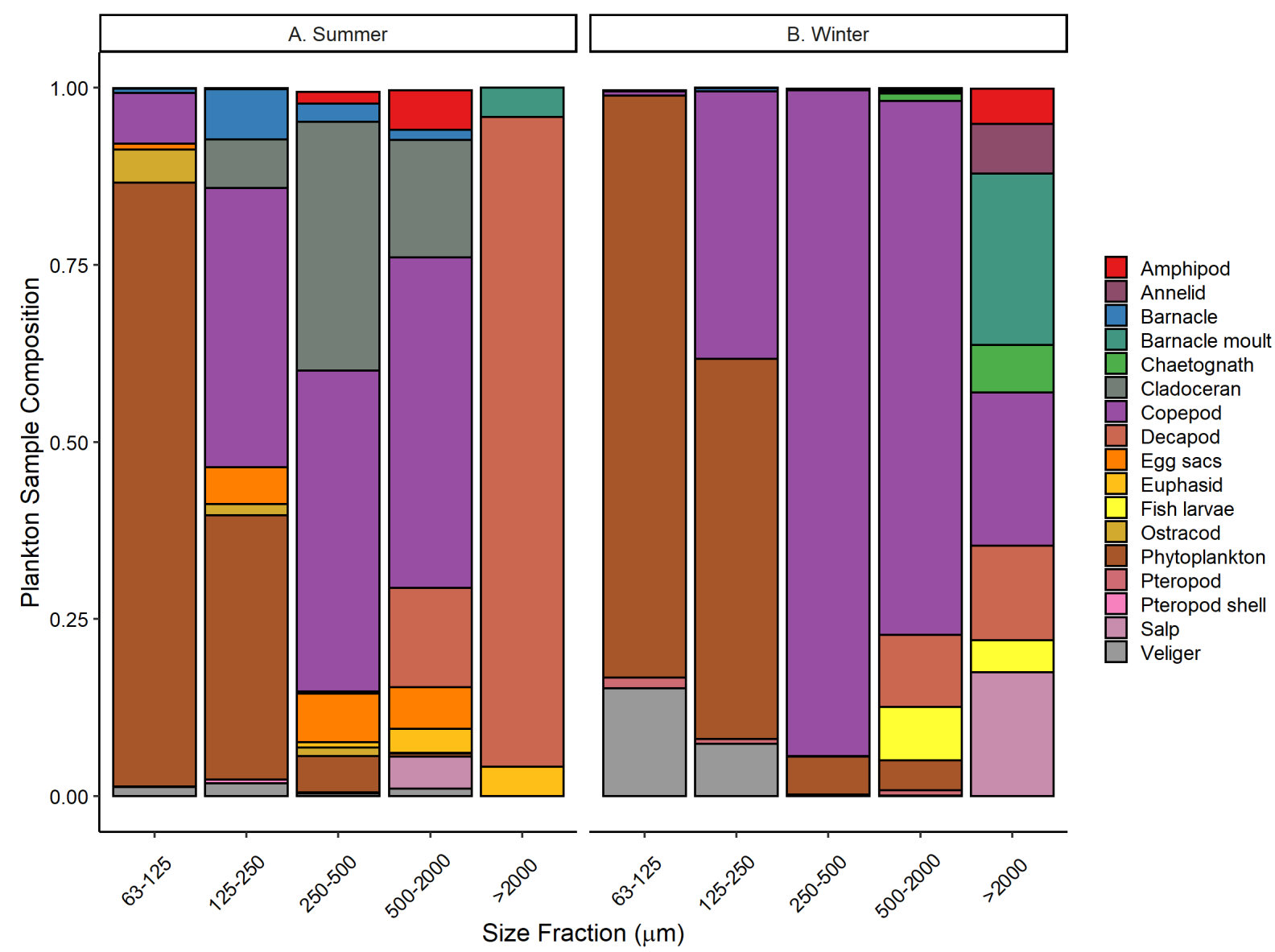

Figure 2. Summer (panel A) and winter (panel B) proportional plankton by size fraction. Plankton groups that constituted $<0.5 \%$ for all size fractions were removed.

for all size fractions. Furthermore, there were no significant differences between size fraction $\delta^{13} \mathrm{C}$ values within any of the regions. When pooling samples from all three regions there were differences among size fractions. The $63-125 \mu \mathrm{m}$ size fraction was more enriched than all other size fractions $(\mathrm{df}=4, \mathrm{~F}=12, \mathrm{p}<$ 0.05 in all cases) which is likely due to the high concentration of enriched KDD in the $63-125 \mu \mathrm{m}$ fraction that was seen microscopically. All size fraction means and standard deviations are available in Table 2.

The $125-250 \mu \mathrm{m}$ fraction along transect 2 in the kelp abundant region had decreasing $\delta^{13} \mathrm{C}$ values with distance from the kelp forest $\left(\mathrm{R}^{2}=0.73, \mathrm{p}=0.03\right)$ (Figure 3). Along transect 6 in the kelp intermediate region the $250-500 \mu \mathrm{m}$ fraction had decreasing $\delta^{13} \mathrm{C}$ values with distance $\left(\mathrm{R}^{2}=0.99, \mathrm{p}=0.06\right)$. Transect 4 in the kelp sparse region had decreasing $\delta^{13} \mathrm{C}$ values with distance for three size fractions as well (63 - $125 \mu \mathrm{m}: \mathrm{R}^{2}=0.87, \mathrm{p}=0.007 ; 125-250 \mu \mathrm{m}: \mathrm{R}^{2}=0.97, \mathrm{p}<$ $0.001 ; 250-500 \mu \mathrm{m}: \mathrm{R}^{2}=0.59, \mathrm{p}=0.04$ ) (Figure 3). Overall, 6 of the 20 size fraction transects showed decreasing $\delta^{13} \mathrm{C}$ values with distance from the kelp forest.

Winter: Proportionally, phytoplankton species made the largest contribution to the $63-125 \mu \mathrm{m}(0.82)$ and the $125-250 \mu \mathrm{m}(0.54)$ surface tows (Figure 2(B)). Copepods were the second most prevalent in the $125-250 \mu \mathrm{m}$ fraction at 0.37 . 
Table 2. Summer and winter size-fractionated surface plankton mean $\delta^{13} \mathrm{C}$ and $\delta^{15} \mathrm{~N}$ values $(\%$ $\pm \mathrm{SD})$.

\begin{tabular}{ccccc}
\hline & \multicolumn{2}{c}{ Summer } & \multicolumn{2}{c}{ Winter } \\
\hline Size fraction $(\mu \mathrm{m})$ & $\begin{array}{c}\text { Mean } \delta^{13} \mathrm{C}( \pm) \\
\text { SD \%o }\end{array}$ & $\begin{array}{c}\text { Mean } \delta^{15} \mathrm{~N}( \pm) \\
\text { SD \%o }\end{array}$ & $\begin{array}{c}\text { Mean } \delta^{13} \mathrm{C}( \pm) \\
\text { SD \%o }\end{array}$ & $\begin{array}{c}\text { Mean } \delta^{15} \mathrm{~N}( \pm) \\
\text { SD \%o }\end{array}$ \\
\hline $63-125$ & $-18.16 \pm 0.98$ & $6.94 \pm 0.93$ & $-20.40 \pm 2.32$ & $8.56 \pm 0.99$ \\
$125-250$ & $-19.14 \pm 0.93$ & $8.06 \pm 1.05$ & $-21.97 \pm 1.17$ & $10.67 \pm 0.52$ \\
$250-500 \mu \mathrm{m}$ & $-19.45 \pm 0.98$ & $8.81 \pm 1.35$ & $-22.13 \pm 1.66$ & $10.59 \pm 0.60$ \\
$500-2000 \mu \mathrm{m}$ & $-19.16 \pm 1.15$ & $8.39 \pm 1.79$ & $-21.49 \pm 1.74$ & $11.35 \pm 1.24$ \\
\hline
\end{tabular}

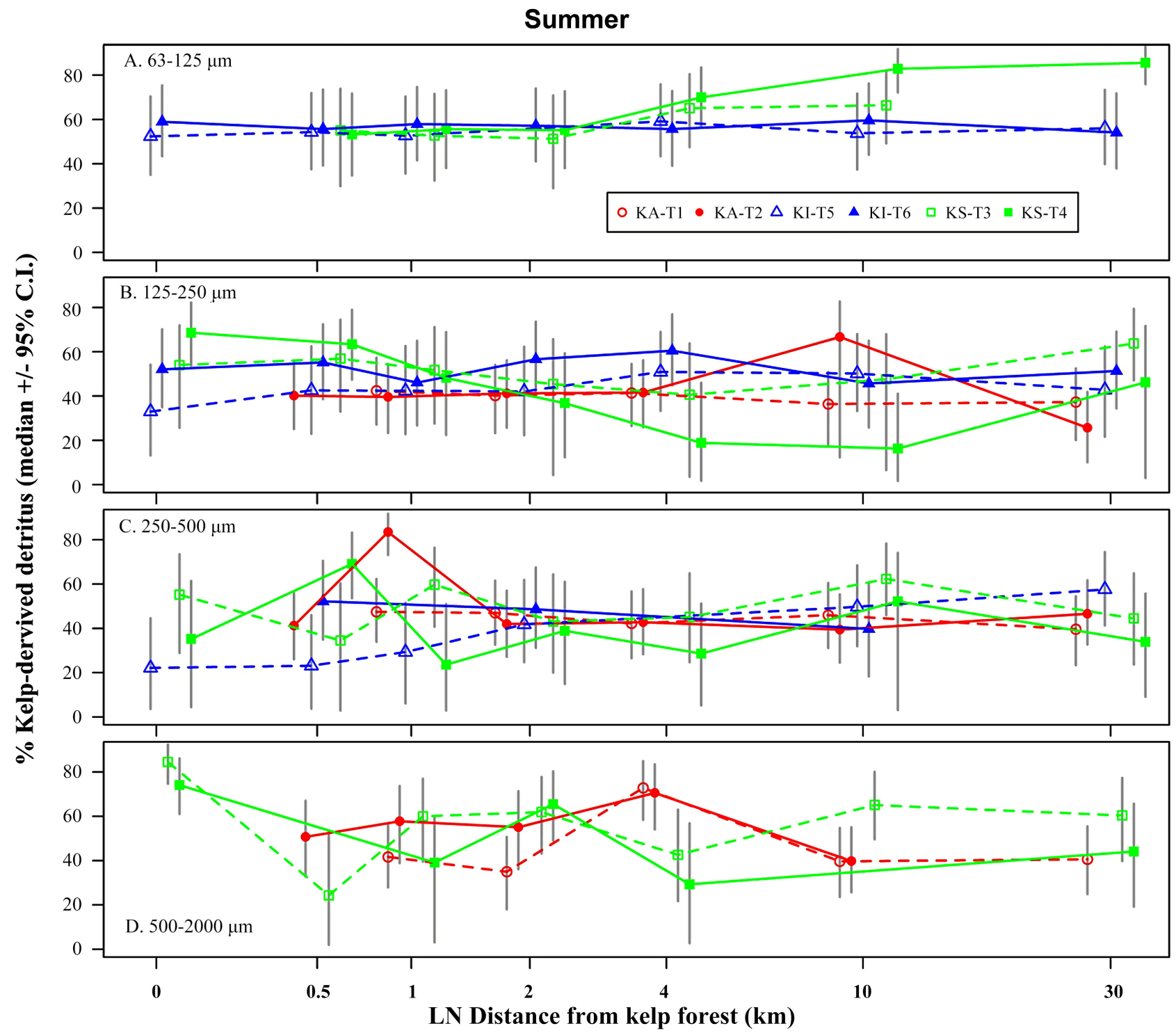

Figure 3. Summer percent kelp-derived detritus contribution (median $\pm 95 \%$ C.I.) to surface $63-125 \mu \mathrm{m}, 125$ - $250 \mu \mathrm{m}, 250$ - 500 $\mu \mathrm{m}$, and $500-2000 \mu \mathrm{m}$ plankton for all three regions. Each point is a single sample $(\mathrm{n}=1)$. Kelp abundant region transects are represented by KA-1 and KA-2, kelp intermediate transects are represented by KI-1 and KI-2, and kelp sparse transects are KS-1 and KS-2. For display purposes, points are jittered horizontally. 
They constituted almost the entire 250 - $500 \mu \mathrm{m}$ zooplankton with a proportion of 0.94 and were the most prevalent in the $500-2000 \mu \mathrm{m}$ fraction (0.75). Veliger larvae made a minor contribution to the $63-125 \mu \mathrm{m}$ fraction at 0.15 and less so to the 125 - $250 \mu \mathrm{m}$ tow (0.07). Decapod and fish larvae constituted 0.1 and 0.08 of the $500-2000 \mu \mathrm{m}$ plankton, respectively (Figure 2(B)).

There were no differences in carbon enrichment for any size fractions among the three regions and there were no within region differences among the plankton size fractions. Furthermore, when kelp abundant and absent regions were combined there were no differences with respect to $\delta^{13} \mathrm{C}$ values among size fractions (kelp intermediate region was not sampled). The kelp sparse region plankton mean $\delta^{13} \mathrm{C}$ values ranged from $-19.80 \%$ for $63-125 \mu \mathrm{m}$ plankton to $-22.39 \%$ for the $250-500 \mu \mathrm{m}$ fraction. The kelp sparse region plankton means ranged from $-19.76 \%$ or the 500 - $2000 \mu \mathrm{m}$ plankton to $-22.20 \%$ for 125 - 250 $\mu \mathrm{m}$ plankton. When all three regions combined, there were no differences in size fraction $\delta^{3} \mathrm{C}$ values. All size fraction means and standard deviations are available in Table 2.

The 125 - $250 \mu \mathrm{m}$ plankton fraction along transect 1 in the kelp abundant region had significantly decreasing $\delta^{13} \mathrm{C}$ values with distance from the kelp forest $\left(\mathrm{R}^{2}=0.68, \mathrm{p}=0.04\right)$ (Figure 4). The $63-125 \mu \mathrm{m}$ fraction along transect 3 in the kelp sparse region also had decreasing $\delta^{13} \mathrm{C}$ values with distance from the kelp forest $\left(R^{2}=0.71, p=0.04\right)$, while transect 4 within this same region was more enriched in ${ }^{13} \mathrm{C}$ with distance $\left(\mathrm{R}^{2}=0.67, \mathrm{p}=0.047\right)$. The $125-250 \mu \mathrm{m}$ plankton along transect 3 had decreasing $\delta^{13} \mathrm{C}$ values with distance $\left(\mathrm{R}^{2}=0.81, \mathrm{p}=0.04\right)$ (Figure 4).

\subsection{Surface Plankton Nitrogen Stable Isotopes}

Summer: With respect to plankton $\delta^{15} \mathrm{~N}$ values, the $500-2000 \mu \mathrm{m}$ size fraction was more enriched in the kelp abundant region compared to the kelp sparse region $\left(\mathrm{p}=0.049\right.$ ). The kelp abundant region's mean $\delta^{15} \mathrm{~N}$ values ranged from $8.32 \%$ or for 125 - $250 \mu \mathrm{m}$ to $9.75 \%$ o for 500 - $2000 \mu \mathrm{m}$ plankton. The kelp intermediate region's mean values ranged from $7.23 \%$ o for 63 - $125 \mu \mathrm{m}$ plankton to $8.08 \%$ for the 250 - $500 \mu \mathrm{m}$ fraction. The kelp sparse region ranged from $6.59 \%$ for the 63 - $125 \mu \mathrm{m}$ fraction to $8.86 \%$ o for the 250 - $500 \mu \mathrm{m}$ fraction. There were no significant within region $\delta^{15} \mathrm{~N}$ differences among the plankton size fractions. When all three regions were combined, the $63-125 \mu \mathrm{m}$ was enriched in ${ }^{15} \mathrm{~N}$ when compared to all other size fractions $(\mathrm{df}=4, \mathrm{~F}=12, \mathrm{p}<0.001$ in all cases), but no other fractions were different. All size fraction means and standard deviations are available in Table 2.

Winter: During the winter, there were no significant differences in plankton $\delta^{15} \mathrm{~N}$ values among the regions. The otter present region $63-125 \mu \mathrm{m}$ plankton was depleted relative to the $125-250 \mu \mathrm{m}$ and $500-2000 \mu \mathrm{m}$ fractions $(\mathrm{p}=0.04$ and $\mathrm{p}<0.01$, respectively). There were no other size fraction differences within this region. Within the kelp sparse region, the $63-125 \mu \mathrm{m}$ fraction was depleted 
Winter

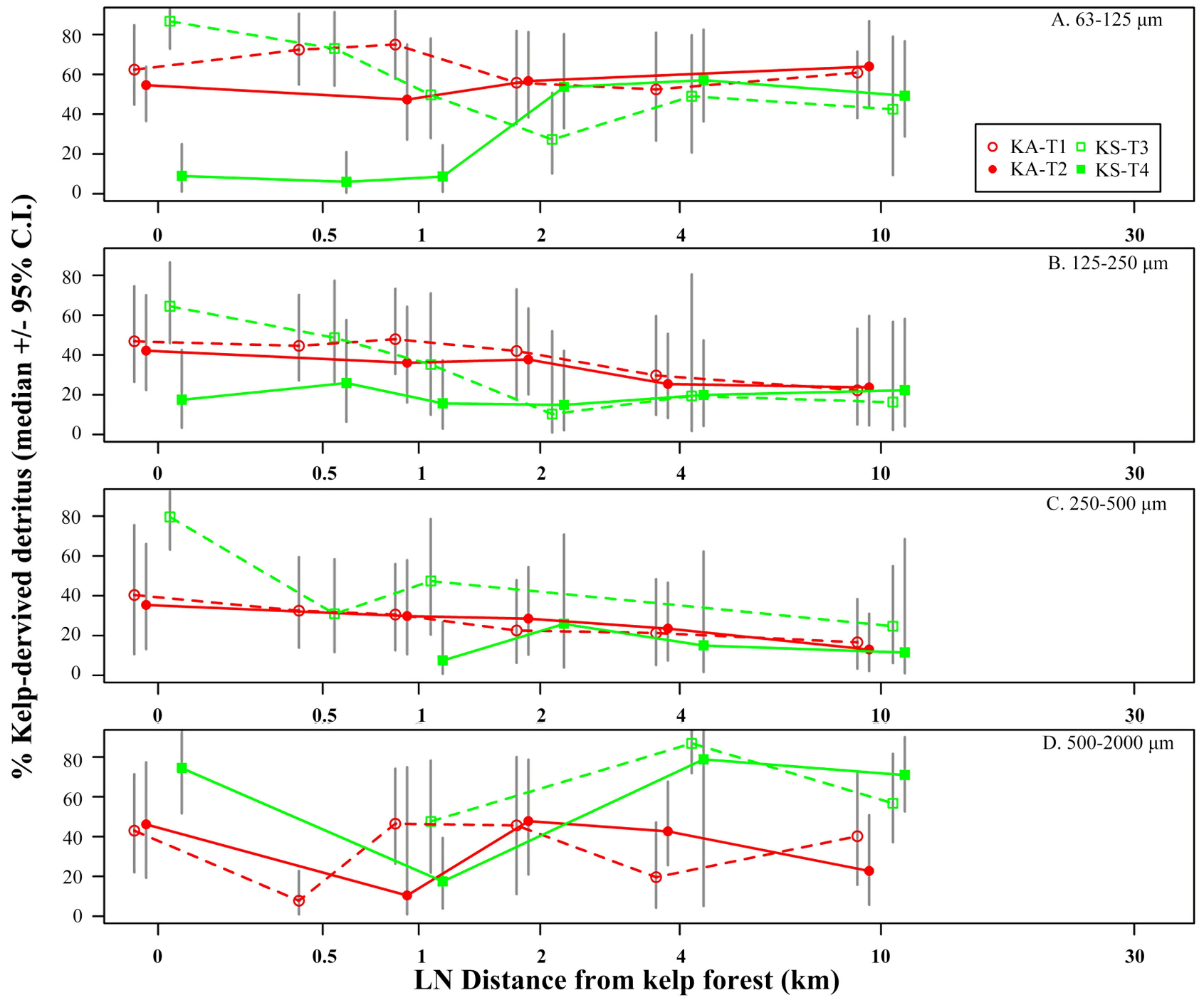

Figure 4. Winter percent kelp-derived detritus contribution (median $\pm 95 \%$ C.I.) to surface 63 - $125 \mu \mathrm{m}, 125$ - $250 \mu \mathrm{m}, 250$ - 500 $\mu \mathrm{m}$, and 500 - $2000 \mu \mathrm{m}$ plankton for otter-present and absent regions. Each point is a single sample $(\mathrm{n}=1)$. Kelp abundant region transects are represented by KA-1 and KA-2, kelp intermediate transects are represented by KI-1 and KI-2, and kelp sparse transects are KS-1 and KS-2. For display purposes, points are jittered horizontally.

in ${ }^{15} \mathrm{~N}$ when compared to all other fractions $(\mathrm{df}=4, \mathrm{~F}=32, \mathrm{p}<0.001$ in all cases); however, no other size fractions were different. The kelp sparse region's plankton mean $\delta^{15} \mathrm{~N}$ values ranged from $9.25 \%$ for the $63-125 \mu \mathrm{m}$ fraction to $11.12 \%$ for the $500-2000 \mu \mathrm{m}$ fraction while the kelp sparse region's values ranged from $7.99 \%$ for the $63-125 \mu \mathrm{m}$ plankton to $11.69 \%$ or the $500-2000$ $\mu \mathrm{m}$ fraction. All size fraction means and standard deviations are available in Table 2.

\subsection{Trophic Level Isotope Fractionation}

Although summer 63 - $125 \mu \mathrm{m}$ plankton $\delta^{13} \mathrm{C}$ was more enriched than the 125 $250 \mu \mathrm{m}, 250-500 \mu \mathrm{m}$ and the $500-2000 \mu \mathrm{m}$ fractions, there was no pattern or 
step-wise enrichment with size fraction. The mean ${ }^{13} \mathrm{C}$ fractionation $( \pm S D)$ was $-0.34 \%$ o $\pm 1.51 \%$ o (i.e. values were more depleted with increasing trophic level) between $63-125 \mu \mathrm{m}$ and these two fractions. There was no difference among winter plankton $\delta^{13} \mathrm{C}$ fractions. Considering these factors, source $\delta^{13} \mathrm{C}$ fractionation and standard deviation were " 0 " for summer and winter.

Because the summer and winter plankton $\delta^{15} \mathrm{~N}$ values for the $63-125 \mu \mathrm{m}$ size fraction were depleted when compared to all larger size fractions, and no other fractions were significantly different, a mean fractionation $( \pm S D)$ for each season was calculated by subtracting the mean of each fraction with the $63-125 \mu \mathrm{m}$ within its respective season. For summer plankton, this value was $1.47 \% \pm$ $0.39 \%$, while for winter it was $2.32 \%$ o $\pm 0.46 \%$.

For benthic organisms' isotope fractionation with trophic level, values from [39] were used as this work applied to marine organisms, and had separate values for herbivores, organisms raised on invertebrates, etc. $\left(\delta^{13} \mathrm{C}: 0.5 \%\right.$ o $\pm 0.13 \%$; herbivores $-\delta^{15} \mathrm{~N}: 2.2 \%$ o $\pm 0.3 \%$, raised on inverts $-\delta^{15} \mathrm{~N}: 1.4 \%$ $\pm 0.21 \%$ ) .

\subsection{Kelp-Derived Detritus Incorporated by Plankton}

Summer: During the summer in the kelp abundant region, the median KDD contributions to plankton ranged from $21 \%$ to $81 \%$ for all size fractions (Figure 3). Median KDD contributions to this fraction remained high and constant with distance from the kelp forest. The two largest fractions were similar in this regard with the exception of a few distances where the median KDD contribution was much higher, such as $1 \mathrm{~km}$ along the $250-500 \mu \mathrm{m}$ fraction. For example, for the 250 - $500 \mu \mathrm{m}$ fraction at $1 \mathrm{~km}$ the median contribution was $81 \%$ (Figure 3 ). Within a size fraction there was large overlap in confidence intervals with distance and between transects at the same distance except for the $500-2000 \mu \mathrm{m}$ fraction where there was greater variability with distance but the two transects were generally similar.

In the kelp intermediate region, median KDD contributions to plankton varied between $16 \%$ and $55 \%$ for all size fractions. It was the highest in $63-125 \mu \mathrm{m}$ plankton with the median $\mathrm{KDD}$ contributions ranging from $47 \%$ to $55 \%$ and remained moderately high and constant with distance from the kelp forest (Figure 3). Median KDD contributions slightly decreased with increasing fraction size. Samples greater than $500 \mu \mathrm{m}$ were not collected for this region.

In the kelp sparse region, median percent KDD contribution to plankton was highly variable with distance and between transects for all size fractions of plankton ranging from low (16\%) to very high (81\%) (Figure 3). Median contributions to the $63-125 \mu \mathrm{m}$ fraction were moderate to very high and increased with distance from the coast. Median contributions to 125 - $250 \mu \mathrm{m}$ plankton had large uncertainty at a number of distances (Figure 3 ). This led to large overlap in percent contributions between the two transects for this size fraction. Large confidence intervals were present for the 250 - 500 and $500-2000 \mu \mathrm{m}$ plankton. This led to a large range of possible contributions across the region for 
these two size fractions.

Winter: In the kelp abundant region, the median KDD contributions to plankton ranged from $4 \%$ to $68 \%$ for all size fractions (Figure 4). Median KDD contributions to the $63-125 \mu \mathrm{m}$ fraction remained high and constant with distance from the kelp forest with large overlap in confidence intervals with distance and between transects. For the $125-250 \mu$ m plankton median KDD contributions decreased moderately with distance and had relatively low overlap in confidence intervals between 0 and $10 \mathrm{~km}$, indicating that there is a low probability that the contributions were similar between these two distances. The 250 $500 \mu \mathrm{m}$ had smaller medians $(13 \%-29 \%)$ relatively to the two smaller fractions and only decreased slightly with distance within the fraction. The $500-2000 \mu \mathrm{m}$ fraction was highly variable $(6 \%-41 \%)$ with distance and had confidence intervals that did not overlap at certain distance.

During the winter in the kelp sparse region, KDD median contributions to plankton were from $4 \%$ to $80 \%$ for all size fractions (Figure 4). The $63-125 \mu \mathrm{m}$ fraction had a strong contrast with respect to KDD contribution between transects as transect 3 medians decreased, from $80 \%$ to $27 \%$, with distance and transect 4 medians increased (from $6 \%$ to $47 \%$, Figure 4). In the $125-250 \mu \mathrm{m}$ plankton, the median KDD contribution decreased with distance and had no overlap in confidence intervals between 0 and $10 \mathrm{~km}$, while along the transect 4 , KDD contributions remained low and constant with distance. The $250-500 \mu \mathrm{m}$ plankton showed a similar decline in contribution with distance. The precipitous decline (from $73 \%$ to $20 \%$ ) was observed between 0 and $0.5 \mathrm{~km}$. The $500-2000$ $\mu \mathrm{m}$ fraction had no trends and was highly variable with distance. The median KDD contributions were from $15 \%$ to $79 \%$ (Figure 4).

\subsection{Kelp-Derived Detritus Incorporated by Benthic Organisms}

Astraea: Paired defatted and untreated Astraea gibberosa samples showed no differences in $\delta^{13} \mathrm{C}$ and $\delta^{15} \mathrm{~N}$ values. Further analyses were only on the untreated samples.

Astraea mean lengths $( \pm \mathrm{SE})$ differed among regions $(\mathrm{df}=2, \mathrm{~F}=29, \mathrm{p}<0.001)$. The kelp abundant region individuals $(3.43 \pm 0.19 \mathrm{~cm})$ were smaller in size compared to the kelp intermediate $(5.4 \pm 0.15 \mathrm{~cm})$ and absent regions $(5.59 \pm$ $0.23 \mathrm{~cm} ; \mathrm{p}<0.001$ in both cases). When all regions were pooled, Astraea $\delta^{13} \mathrm{C}$ and $\delta^{15} \mathrm{~N}$ values increased with length $\left(\mathrm{R}^{2}=0.47, \mathrm{p}<0.001\right.$, and $\mathrm{R}^{2}=0.11, \mathrm{p}=$ 0.03 , respectively).

There was considerable within region $\delta^{13} \mathrm{C}$ variation among sampling sites ( $\mathrm{df}$ $=7, \mathrm{~F}=9, \mathrm{p}<0.001$ ) which did not allow samples from within the same region to be pooled for modeled KDD contribution estimates because it led to bimodal posterior probability distributions. This variation did not exist for $\delta^{15} \mathrm{~N}$ values.

Percent KDD incorporated by Astraea showed among and within region variation with large differences in percent KDD contribution among all region (Figure 5). Astraea collected in the kelp abundant region had $0 \%$ to $27 \%$ (range 


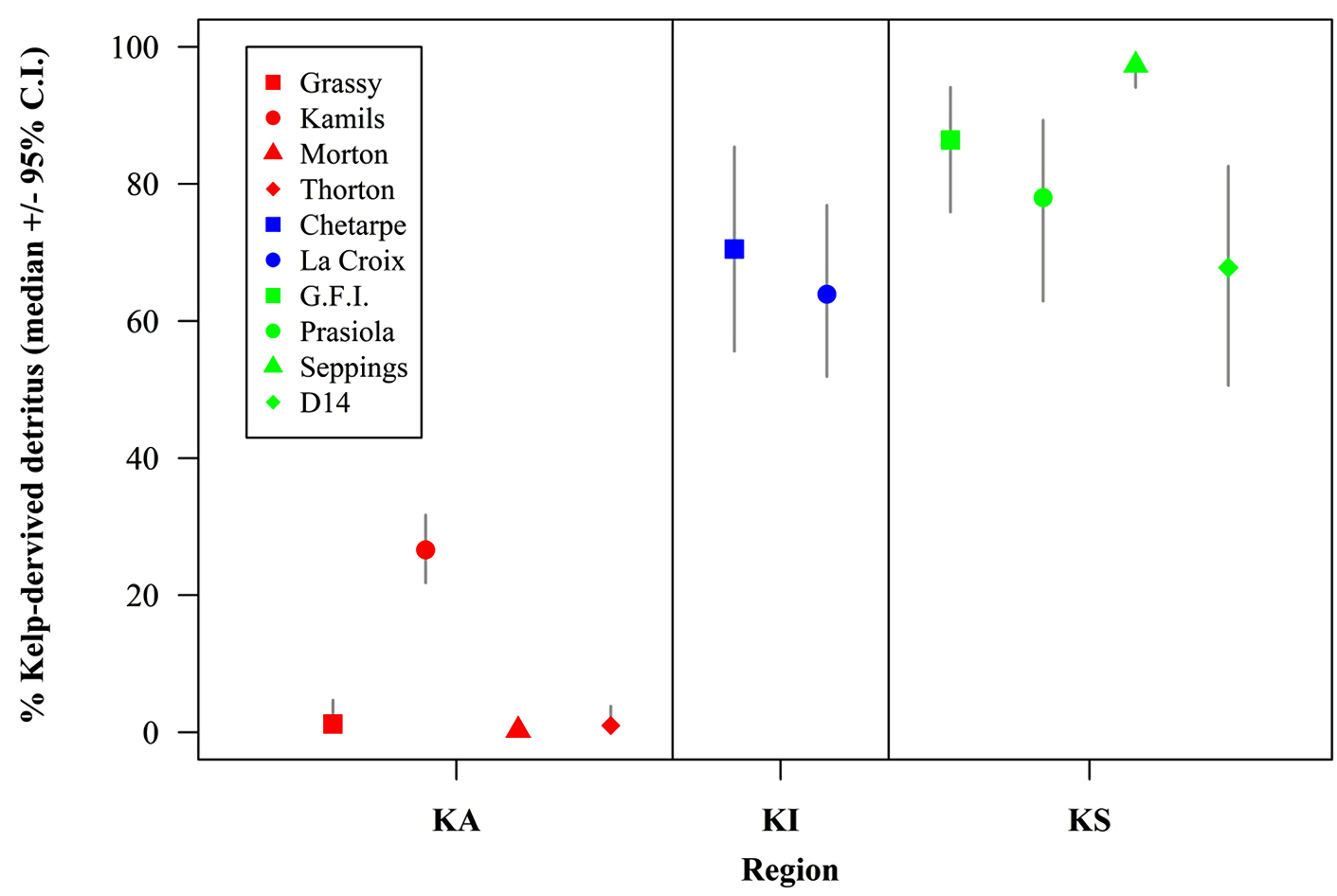

Figure 5. Percent kelp-derived detritus contribution (median $\pm 95 \%$ C.I.) to the diet of Astraea gibberosa (red turban snail) during the summer. Within region sites are represented by different symbols. Samples sizes from left to right are Grassy: 1, Kamils: 7, Morton: 3, Thorton: 2, Chetarpe: 5, La Croix: 1, D14: 5, G.F.I.: 3, Prasiola: 5 and Seppings: 11.

of medians) of KDD subsidy. In the kelp intermediate region, KDD contribution medians ranged from $64 \%$ to $71 \%$. The kelp sparse region samples were composed of the largest percent KDD with median contributions from $68 \%$ to $97 \%$ (Figure 5). Seppings Island had the highest median percent KDD contribution (97\%) compared to any sampling site.

Chlamys. When all three regions were combined, scallop summer $\delta^{13} \mathrm{C}$ values increased with shell width $\left(\mathrm{R}^{2}=0.43, \mathrm{p}<0.001\right)$. This led to modeling KDD contribution to scallops grouped by shell width. Generally, during the summer percent KDD contribution to pink and spiny scallops was higher in the kelp sparse region, especially in the larger size classes (Figure 6). When all otter present-region size classes were combined, median percent KDD contributions were from $25 \%$ to $60 \%$ with the smallest size class $(1.1-1.5 \mathrm{~cm})$ having the largest median percent contribution of $60 \%$. Only one size class was collected from the kelp intermediate region during the summer. This size fraction $(2.6-3 \mathrm{~cm})$ had a percent KDD contribution of $62 \%$. Median percent KDD contributions to the kelp sparse region scallops ranged from $75 \%$ to $92 \%$. There was a trend towards increasing KDD contribution with size-class. Scallops of the smallest size class $(1.1-1.5 \mathrm{~cm})$ had a median percent contribution of $62 \%$ and the largest size class $(3.6-4 \mathrm{~cm})$ had a contribution of $81 \%$.

During the winter, scallops were only retrieved during dredging in the kelp abundant region. Percent KDD contribution to these scallops ranged from 40 to 


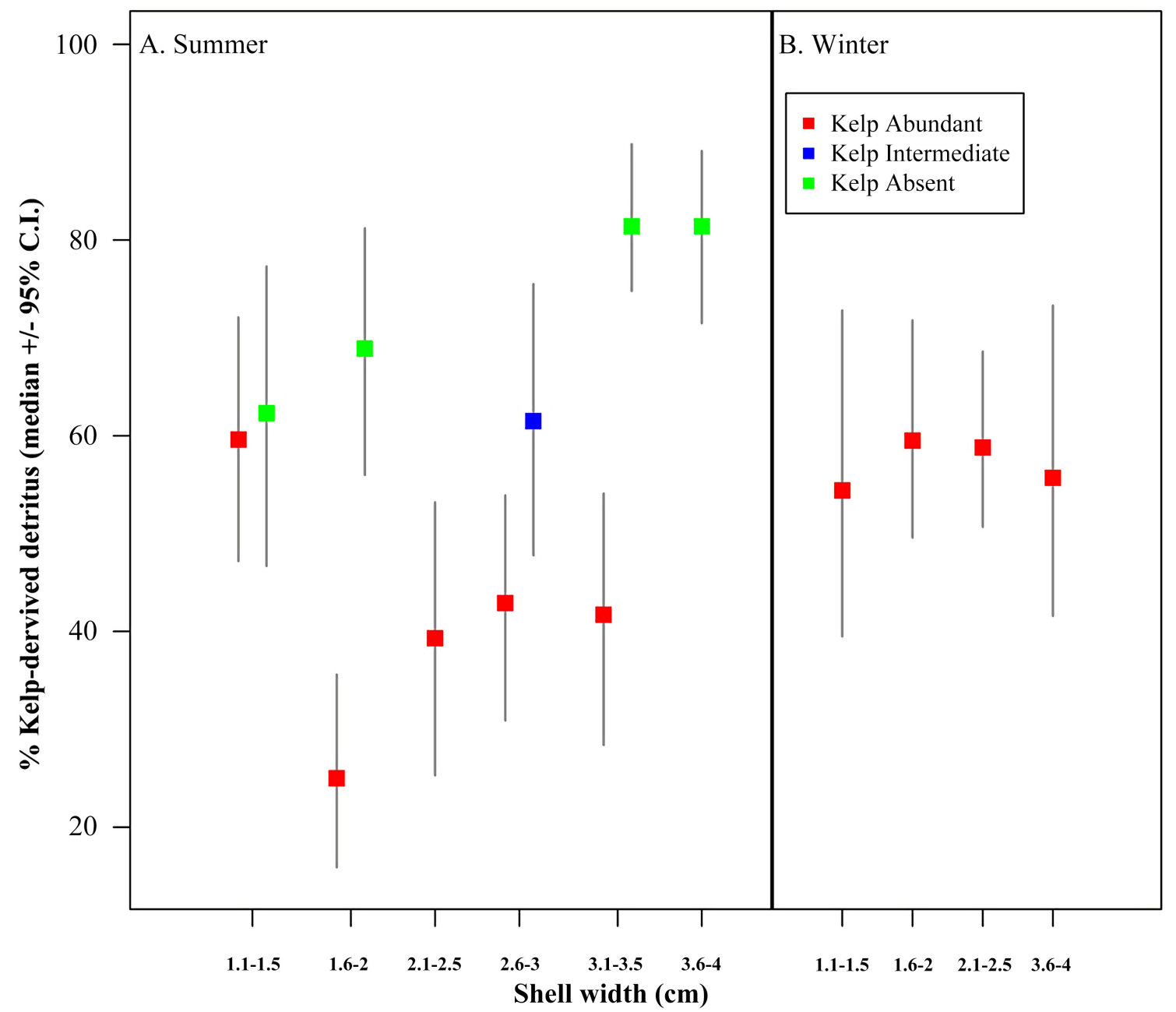

Figure 6. Percent kelp-derived detritus contribution (median $\pm 95 \%$ C.I.) to the diet of Chlamys sp. (pink scallops) by shell width $(\mathrm{cm})$. Winter samples were only retrieved from the kelp abundant region. Sample sizes from left to right are: $1,1,9,1,1,3,1,2,4,3,1,6,7$ and 1 . Samples of the same size class are jittered for display purposes.

$73 \%$ and there was no trend of increasing contribution with larger size classes (Figure 6). There was a trend of higher contribution during the winter relative to the summer in the kelp abundant region.

Anomurans: Paired t-tests of hermit crab samples that were split in half and one half was treated with acid and the other half left untreated showed no change in $\delta^{13} \mathrm{C}$ and $\delta^{15} \mathrm{~N}$ values. Further analyses were only performed on untreated samples.

Hermit crab $\delta^{13} \mathrm{C}$ and $\delta^{15} \mathrm{~N}$ values increased with carapace width during the summer $\left(\mathrm{R}^{2}=0.40, \mathrm{p}<0.001\right.$ and $\mathrm{R}^{2}=0.14, \mathrm{p}<0.001$, respectively) and during the winter with $\delta^{13} \mathrm{C}\left(\mathrm{R}^{2}=0.35, \mathrm{p}=0.003\right)$. Therefore, modeled KDD contribution estimates were determined for hermit crabs grouped in $0.1 \mathrm{~cm}$ bin intervals.

During the summer in the kelp abundant region, the two smallest size classes $(0.2$ and $0.3 \mathrm{~cm})$ had the lowest contribution of KDD with the $0.2 \mathrm{~cm}$ size class having a median percent contribution $47 \%$. There was a trend towards increasing KDD contribution with increasing size (little confidence interval overlaps) as 
the $0.8 \mathrm{~cm}$ size class having a possible median contribution of $76 \%$ (Figure 7). In the kelp intermediate region, median percent

KDD contributions to hermit crabs were from $56 \%$ to $79 \%$. The $0.3 \mathrm{~cm}$ size class had the lowest contribution at $56 \%$, while the $0.4 \mathrm{~cm}$ size class had the largest at 79\%. In the kelp sparse region, the percent KDD contribution was high in all size classes. The median contributions were from $69 \%$ to $89 \%$ with 3 size classes having possible KDD contributions $\geq 90 \%$ for 3 size classes $(0.3,0.4$ and $0.6 \mathrm{~cm}$ ). The kelp sparse region 0.3 and 0.4 size classes had a larger percent KDD contribution than the similar kelp abundant region size classes.

During the winter, samples were only obtained in the kelp abundant and absent regions. Possible percent-kelp derived detritus contributions remained as high as during the summer. The median percent contribution for the $0.7 \mathrm{~cm}$ size class in the kelp abundant region was $73 \%$ (Figure 7), which was within the confidence intervals for most summer size-classes. In the kelp sparse region, the
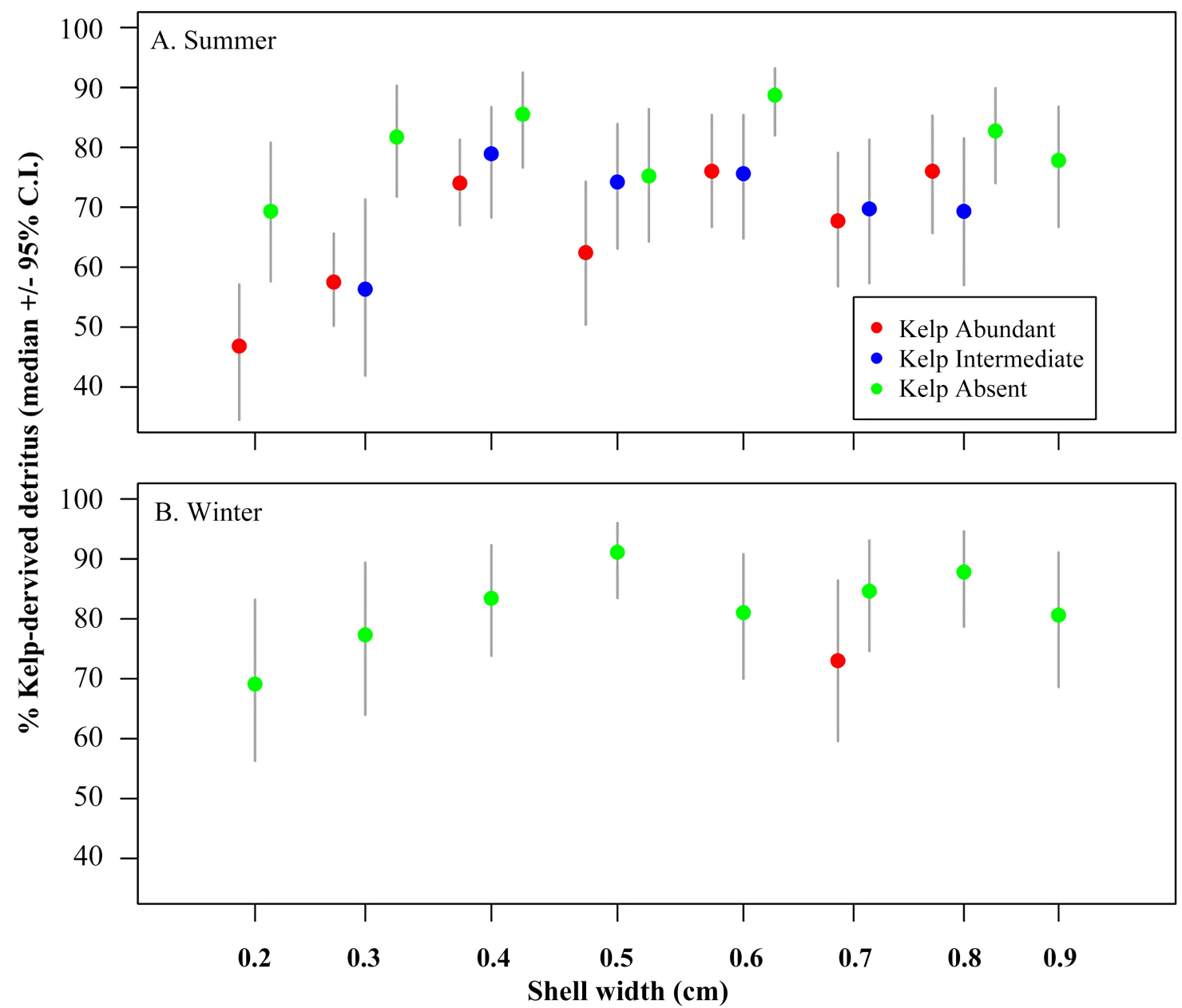

Figure 7. Percent kelp-derived detritus contribution (median $\pm 95 \%$ C.I.) to the diet of hermit crabs (Anomurans) by shell width $(\mathrm{cm})$ for summer and winter along the kelp abundance gradient. Samples are pooled from a variety of distances from the kelp forests. Summer sample sizes from left to right; kelp abundant: 3, 5, 6, 1, 2, 1, 1; kelp intermediate: $1,4,5,3,2,1$; kelp absent: $2,14,2,1,4,1,1$. Winter sample sizes from left to right; kelp abundant: 1 ; kelp sparse: $2,1,5,6,3,2,1$. Samples of the same width are jittered for display purposes. 
median percent KDD contributions were from $69 \%$ to $91 \%$ when all size classes were combined. The $0.2 \mathrm{~cm}$ size class had the lowest contribution $69 \%$ and the $0.5 \mathrm{~cm}$ size class had the highest contribution at $91 \%$. However, in general, there was high overlap in confidence intervals among most size-classes.

\section{Discussion}

Contrary to expectation, regional differences in kelp contribution to primary consumers were not detected despite a 20 -fold difference in the giant kelp ( $\mathrm{Ma}$ crocystis pyrifera) abundance between regions. Furthermore, no consistent decrease in kelp contribution to primary consumers with increasing distance from source kelp forests within any region was evident. Nevertheless, during the winter, the KDD contribution to plankton was lower than during the summer with pronounced variability between regions and along transects away from kelp forests. The KDD contribution to benthic organisms was also high in all regions during both summer and winter. The exception was Astraea in the kelp abundant region where KDD contribution was on average more than 3-fold lower than the kelp sparse region.

\subsection{Plankton $\delta^{13} \mathrm{C}$ Variability}

In general, some size fractions of plankton along a particular transect during both summer and winter showed significant decreases in $\delta^{13} \mathrm{C}$ values with the distance from kelp forests. This was expected in the kelp abundant region because of higher kelp production, hence lateral transport and faster dissipation of the ${ }^{13} \mathrm{C}$ enriched organic matter away from the kelp forest. The shelf currents may facilitate this as shown for the POM [27] [64]. The coastal upwelling and downwelling conditions could further control the KDD contribution to the POM [65]. The kelp intermediate region only had decreasing $\delta^{13} \mathrm{C}$ values with distance from the kelp forest for one $(250-500 \mu \mathrm{m})$ size fraction along both transects. While, this may reflect the inability of small plankters of this fraction to feed on kelp-derived production, other explanations are likely in play. For example, accumulation of lipids that are ${ }^{13} \mathrm{C}$ depleted [66] may affect their isotopic ratios [67]. Plankton $\delta^{13} \mathrm{C}$ from the kelp sparse region was more depleted along one transects oceanward for all plankton smaller than $500 \mu \mathrm{m}$. This coincides with their food source (surface POM) being more depleted with distance along this transect [27]. On the other hand, along the nearby transect, plankton remained relatively enriched in ${ }^{13} \mathrm{C}$ with distance from the kelp forest. This may result from the presence of KDD or blooming phytoplankton in these samples [27] [68]. Wide confidence intervals, due to similar isotopic values of KDD and blooming phytoplankton as well as highly dynamic oceanographic environment in this region do not allow answering this question with high certainty [22] [27] [69].

\subsection{Plankton $\delta^{15} \mathrm{~N}$ Variability}

Plankton $\delta^{15} \mathrm{~N}$ variability is affected by the $\delta^{15} \mathrm{~N}$ variability of its food sources 
[70], isotope fractionation during assimilation [71], excretion [72], and their trophic level [36] [73]. A wide variety of animals are enriched in ${ }^{15} \mathrm{~N}$ by $\sim 3.4 \%$ relative to their diet and trophic position can be estimated from their $\delta^{15} \mathrm{~N}$ values [36] [39].

KDD can support higher densities of consumers at higher trophic levels [4] [20] [52]. In this study, only $\delta^{15} \mathrm{~N}$ differences within plankton size fractions were found during the summer between the kelp abundant and absent regions. For example, the $500-2000 \mu \mathrm{m}$ size fraction within the kelp abundant region was $1.9 \%$ enriched compared to $<250 \mu \mathrm{m}$ size fractions. However, this is likely not biologically significant, nor is it prevalent enough to conclude whether or not kelp abundant region plankton are feeding at higher trophic levels. There were no within-region differences among $\delta^{15} \mathrm{~N}$ values of plankton size fractions, which inhibits the conclusion that larger size fractions of plankton were feeding at higher trophic levels [74].

\subsection{Incorporation of Kelp-Derived Detritus by Plankton}

KDD contribution to majority size fractions of zooplankton was moderate to high during the summer in all regions. Contrary to our predictions but in agreement with the surface POM, no regional and along transects differences in kelp contribution were evident. The two largest zooplankton size fractions (250 - 500 and $500-2000 \mu \mathrm{m}$ ) showed the largest spatial variability. Furthermore, uncertainties in the KDD contribution estimates were greatest for the kelp sparse region. This, however, could be misleading to how important KDD is in this region because the high uncertainty in the modeled estimates likely resulted from the inclusion of Nereocystis being the major, and possibly the only, kelp species contributing to POM. This species had a mean $\delta^{13} \mathrm{C}$ value of $-18.31 \%$, which was the closest to blooming phytoplankton values of $-18.91 \%$ than in any other region [27]. Similarity in source isotope values leads to uncertainty (i.e. large confidence intervals) in modeled contribution estimates [62]. In general, for a given distance and region, median KDD contributions to plankton were similar to median KDD contributions to POM [27].

During winter, there was a greater spatial variability within regions and pronounced differences in detritus contributions between transects. In general, the KDD contribution was similar during both seasons. Nevertheless, during the winter, kelp contribution was patchier, especially in the kelp sparse region.

These results indicate that the moderate to high KDD contribution to plankton year-round at all distances offshore of the kelp abundant region is likely due to the oceanographic conditions specific to this region, that alter the abundance of KDD. Although our estimates are potentially high, it was predicted that the KDD contribution would be consistently higher, particularly during upwelling events [64] [65] [69]. Summer growth and accumulation of kelp biomass are released into the environment through senescence and dissolved organic carbon [23] [75]. Winter storms accelerate the breakdown of kelp and release the bio- 
mass gained in the summer during the winter [5] [69]. Harris [76] postulated that the water beyond the continental shelf off northern Vancouver Island was similar to shelf water due to the narrowing (to $\sim 5 \mathrm{~km}$ ) continental shelf along the northern part of Vancouver Island. Wind driven upwelling filaments and eddies regularly form off Brooks Peninsula, just north of the kelp abundant region, moving a significant proportion of the nutrients, phytoplankton and zooplankton off the shelf into the adjacent pelagic environment [44] [77]. Similarly, this mechanism would draw the nearshore KDD away from shore. During our study, we collected total POM near the ocean floor in the kelp abundant region (data not presented here), with ${ }^{13} \mathrm{C}$ depleted by $1.6 \%$ relative to surface POM during the summer and $1.1 \%$ during the winter. Harris [76] explained the SST gradient along the WCVI, with lower temperatures of the kelp abundant region, as a result of the narrow shelf because upwelled water off the kelp abundant region has a shorter distance to travel and less time to warm before being transported off the shelf. This could have implications for water residence time over the shelf and upwelled water and particles with depleted ${ }^{13} \mathrm{C}$ being in the nearshore area depleting the surface POM $\delta^{13} \mathrm{C}$. Although KDD production may be relatively high in this region it is possible that the retention of this production in the region is reduced by regional oceanography and/or diluted by upwelled, ${ }^{13} \mathrm{C}$ depleted POM [27].

\subsection{Incorporation of Kelp-Derived Detritus by Benthic Invertebrates}

KDD incorporated by the snail Astraea gibberosa differed greatly within regions and among sites within the kelp abundant region and therefore could not be combined for mixing model estimates. Individuals from Kamils Island had the highest KDD (median 27\%) contribution compared to other sites ( $\leq 5 \%)$. Surprisingly, the KDD contribution to the other two regions was high with a median contribution of $68 \%-97 \%$. One explanation for these results may be that abundant kelp populations in the kelp abundant region is also associated with abundant understory red algae in the kelp abundant region [78]. Red algae are highly depleted in ${ }^{13} \mathrm{C}(\sim-30 \%$; [79]) and could be an abundant food source in the kelp abundant region leading to the low contribution of kelp-derived production to these organisms, or, as some have suggested, there is superiority in mixed diets compared to single foods [80] [81] [82]. Second, the individuals in the kelp abundant region were approximately $2 \mathrm{~cm}$ smaller and thus more ${ }^{13} \mathrm{C}$ depleted. Sea otter populations at equilibrium density are thought to be food limited [83] and changes in prey availability will influence sea otter foraging behavior [84]. Sea otters preferentially feed on sea urchins when available [46] [84]. However, in areas where otters have been established for quite some time large urchins are absent [46] and otters consume less preferred prey that has become more energetically profitable [85] [86]. It is therefore plausible that in the kelp abundant region large Astraea heavily preyed upon and reduced in abundance. Finally, smaller Astraea may eat less kelp tissue but consume diatoms and bacteria on 
kelp blades that are relative ${ }^{13} \mathrm{C}$ depleted [33] [87] [88]. Also, smaller Astraea could be structurally limited due to smaller or weaker mouth parts and not be able to consume, or possibly even digest kelp, due to its rigidness [31].

In general, modeled estimates of KDD contribution to benthic invertebrates were similar, among regions and between seasons. The incorporation of KDD by Calliostoma was similar and high $(>60 \%)$ for all regions. This was not the case for Chlamys spp. as kelp sparse region scallops had higher contributions of KDD than the kelp abundant region for most size classes. The kelp intermediate region was midway between the other two regions. During the winter there was a trend towards a higher contribution of KDD for all size classes of scallop in the kelp abundant region. Hermit crabs showed a similar pattern except for the two smallest size classes $(0.2$ and $0.3 \mathrm{~cm})$ in the kelp abundant region were composed of less KDD than the kelp sparse region. This is evidence of possible hermit crab body size effects with respect to KDD consumption. Again, during the winter the contribution remained as high as during the summer, which was consistent across all size classes.

The surprisingly high contribution of KDD to consumers from the kelp sparse region during the summer and winter may be explained as follows. First, although giant kelp abundance is 20-times higher in the kelp abundant region, there is still an ample standing stock of other kelp species present in the kelp sparse region [78] contributing to this region's POM pool. Second, the $\delta^{13} \mathrm{C}$ values of the most abundant Nereocystis in this region appeared similar to the values of blooming phytoplankton resulted in highly uncertain modeled KDD contributions. Altering the kelp proportions in this region from 100\% Nereocystis to include Macrocystis would enrich the kelp $\delta^{13} \mathrm{C}$ value used in the mixing model and potentially decrease the maximum possible contribution of the giant kelp KDD to organisms within this region. Estimated uncertainty was higher in both regions during the winter because kelp values used in the mixing model had larger within region variability. The presence or absence of sea otters indirectly alters kelp forest species composition and grazer-kelp interactions through successional processes [53] [89], and therefore, may affect consumer diets and isotope values. Drift kelp and KDD are known to accumulate on gentle slopes and depressions as well as in areas of low current velocities suggesting importance of local hydrodynamics [90]. Biber [91] reports that areas with low standing stock of drift macroalgae and high currents can still have significant fluxes of drift pass through. These processes can lead to shifts in consumer spatial distributions in response to food availability [90] leading to isotope enrichment and potentially obscuring predicted patterns.

In conclusion, it appears that the local oceanography, kelp forest species composition, kelp species isotope variation, and kelp's similarity with blooming phytoplankton isotope values led to highly variable and at times counterintuitive results leading to uncertainty in the modeled KDD contributions. Nevertheless, in regions with dynamic hydrodynamics (i.e. fast currents, upwellings/downwellings, filament and eddy formation) that characterize narrow shelf regions, the KDD 
contribution to the various pelagic and benthic ecosystems is modestly high irrespective of the sea otter occupation. This is largely driven by the redundancy in the kelp species composition when multi-year Macrocystis species can be replaced by the annual species such as Nereocystis. Our study could uncover the inter-annual variability in the KDD contributions, which may hypothetically be more pronounced in the absence of Macrocystis kelp forests [22]. Ultimately, our findings speak to how widespread or limited the indirect effects of otters

(e.g., kelp forest community succession), and other sources of ecosystem change, can be and are helpful in applications of ecosystem based coastal management.

\section{Acknowledgements}

The authors would like to acknowledge Sven Kaehler who participated in sample collections and contributed analysis for this study. We thank Michel Jutras, Matthew Eaton, John Richards, Janet Pierce, Chris Payne, and Larysa Pakhomova for assistance in the field. We are grateful to the Bamfield Marine Sciences Centre for letting use their benthic dredge. We thank the coastal communities of Bamfield, Tofino, and Kyuquot for their hospitality. Thanks to Gerald Singh for sharing his kelp isotope data and the BCCES project team for their support. We thank the National Science and Engineering Research Council (NSERC) of Canada for funding this study.

\section{Conflicts of Interest}

The authors declare no conflicts of interest regarding the publication of this paper.

\section{References}

[1] Vetter, E.W. (1994) Hotspots of Benthic Production. Nature, 372, 47. https://doi.org/10.1038/372047a0

[2] Polis, G.A., Anderson, W.B., Holt, R.D., Anderson, B. and Polis, A. (1997) Toward an Integration of Landscape and Food Web Ecology: The Dynamics Spatially Subsidized Food Webs. Annual Review of Ecology and Systematics, 28, 289-316. https://doi.org/10.1146/annurev.ecolsys.28.1.289

[3] Harrold, C., Light, K. and Lisin, S. (1998) Organic Enrichment of Submarine-Canyon and Continental-Shelf Benthic Communities by Macroalgal Drift Imported from Nearshore Kelp Forests. Limnology and Oceanography, 43, 669-678. https://doi.org/10.4319/lo.1998.43.4.0669

[4] Polis, G.A. and Hurd, S.D. (1996) Linking Marine and Terrestrial Food Webs: Allochthonous Input from the Ocean Supports High Secondary Productivity on Small Islands and Coastal Land Communities. The American Naturalist, 147, 396-423. https://doi.org/10.1086/285858

[5] Dayton, P.K. (1985) Ecology of Kelp Communities. Annual Review of Ecology and Systematics, 16, 215-245. https://doi.org/10.1146/annurev.es.16.110185.001243

[6] Mann, K.H. (1973) Seaweeds: Their Productivity and Strategy for Growth. Science, 182, 975-981. https://doi.org/10.1126/science.182.4116.975

[7] Coon, D. (1982) Primary Production of Macroalgae in North Pacific America. In: 
Zaborsky, O.R., Ed., CRC Handbook of Bisolar Resources, CRC Press, Boca Raton, FL, 447-454.

[8] Abdullah, M.I. and Fredriksen, S. (2004) Production, Respiration and Exudation of Dissolved Organic Matter by the Kelp Laminaria hyperborea along the West Coast of Norway. Journal of the Marine Biological Association of the UK, 84, 887-894. https://doi.org/10.1017/S002531540401015Xh

[9] Rassweiler, A., Reed, D.C., Harrer, S.L. and Nelson, J.C. (2018) Improved Estimates of Net Primary Production, Growth, and Standing Crop of Macrocystis pyrifera in Southern California. Ecology, 99, 2132. https://doi.org/10.1002/ecy.2440

[10] Foreman, R. (1984) Studies on Nereocystis Growth in British Columbia, Canada. Hydrobiologia, 116/117, 325-332. https://doi.org/10.1007/BF00027696

[11] Druehl, L.D. and Wheeler, W.N. (1986) Population Biology of Macrocystis integrifolia from British Columbia, Canada. Marine Biology, 90, 173-179. https://doi.org/10.1007/BF00569124

[12] Pauly, D. and Christensen, V. (1995) Primary Production Required to Sustain Global Fisheries. Nature, 374, 255-257. https://doi.org/10.1038/374255a0

[13] Hahm, D. and Kim, K. (2001) An Estimation of the New Production in the Southern East Sea Using Helium Isotopes. Journal of the Korean Society of Oceanography, 36, 19-26.

[14] Parsons, T. and Lalli, C. (1988) Comparative Oceanic Ecology of the Plankton Communities of the Subarctic Atlantic and Pacific Oceans. Oceanography and Marine Biology Annual Review, 26, 317-359.

[15] Whitney, F., Wong, C. and Boyd, P. (1998) Interannual Variability in Nitrate Supply to Surface Waters of the Northeast Pacific Ocean. Marine Ecology Progress Series, 170, 15-23. https://doi.org/10.3354/meps170015

[16] Kaehler, S., Pakhomov, E.A. and McQuaid, C. (2000) Trophic Structure of the Marine Food Web at the Prince Edward Islands (Southern Ocean) Determined by $\delta^{13} \mathrm{C}$ and $\delta^{15} \mathrm{~N}$ Analysis. Marine Ecology Progress Series, 208, 13-20.

https://doi.org/10.3354/meps208013

[17] Kaehler, S., Pakhomov, E.A, Kalin, R. and Davis, S. (2006) Trophic Importance of Kelp-Derived Suspended Particulate Matter in a Through-Flow Sub-Antarctic System. Marine Ecology Progress Series, 316, 17-22. https://doi.org/10.3354/meps316017

[18] Hill, J., McQuaid, C. and Kaehler, S. (2006) Biogeographic and Nearshore-Offshore Trends in Isotope Ratios of Intertidal Mussels and Their Food Sources around the Coast of Southern Africa. Marine Ecology Progress Series, 318, 63-73. https://doi.org/10.3354/meps318063

[19] dos Santos Fonseca, A.L., Marinho, C.C. and de Assis Esteves, F. (2015) Aquatic Macrophytes Detritus Quality and Sulfate Availability Shape the Methane Production Pattern in a Dystrophic Coastal Lagoon. American Journal of Plant Sciences, 6, 1675-1684. https://doi.org/10.4236/ajps.2015.610167

[20] Moore, J.C., Berlow, E.L., Coleman, D.C., Ruiter, P.C., Dong, Q., Hastings, A. Johnson, N.C., McCann, K.S., Melville, K., Morin, P.J., Nadelhoffer, K., Rosemond, A.D., Post, D.M., Sabo, J.L., Scow, K.M., Vanni, M.J. and Wall, D.H. (2004) Detritus, Trophic Dynamics and Biodiversity. Ecology Letters, 7, 584-600. https://doi.org/10.1111/j.1461-0248.2004.00606.x

[21] Krumhansl, K.A. and Scheibling, R.E. (2012) Production and Fate of Kelp Detritus. Marine Ecology Progress Series, 467, 281-302. https://doi.org/10.3354/meps09940 
[22] Krumhansl, K.A., Lauzon-Guay, J.-S. and Scheibling, R.E. (2014) Modelling Effects of Climate Change and Phase Shifts on Detrital Production of a Kelp Bed. Ecology, 95, 763-774. https://doi.org/10.1890/13-0228.1

[23] Clasen, J.L. and Shurin, J.B. (2015) Kelp Forest Size Alters Microbial Community Structure and Function on Vancouver Island, Canada. Ecology, 96, 862-872. https://doi.org/10.1890/13-2147.1

[24] Filbee-Dexter, K., Wernberg, T., Norderhaug, K.M., Ramirez-Llodra, E. and Pedersen, M.F. (2018) Movement of Pulsed Resource Subsidies form Kelp Forests to Deep Fjords. Oecologia, 187, 291-304. https://doi.org/10.1007/s00442-018-4121-7

[25] Yorke, C.E., Miller, R.J., Page, H.M. and Reed, D.C. (2013) Importance of Kelp Detritus as a Component of Suspended Particulate Organic Matter in Giant Kelp Macrocystis pyrifera Forests. Marine Ecology Progress Series, 493, 113-125. https://doi.org/10.3354/meps10502

[26] Feehan, C.J., Grauman-Boss, B.C., Strathmann, R.R., Dethier, M.N. and Duggins, J.O. (2018) Kelp Detritus Provides High-Quality Food for Sea Urchin Larvae. Limnology and Oceanography, 63, S299-S306. https://doi.org/10.1002/lno.10740

[27] Ramshaw, B.C., Pakhomov, E.A., Markel, R.W. and Kaehler, S. (2017) Quantifying Spatial and Temporal Variations in Phytoplankton and Kelp Isotopic Signatures to Estimate the Distribution of Kelp-Derived Detritus off the West Coast of Vancouver Island, Canada. Limnology and Oceanography, 62, 2133-2153. https://doi.org/10.1002/lno.10555

[28] Anderson, W.B. and Polis, G.A. (1998) Marine Subsidies of Island Communities in the Gulf of California: Evidence from Stable Carbon and Nitrogen Isotopes. Oikos, 81, 75-80. https://doi.org/10.2307/3546469

[29] Russell-Hunter, W. (1970) Aquatic Productivity. Macmillan, New York.

[30] Duggins, D.O. and Eckman, J.E. (1997) Is Kelp Detritus a Good Food for Suspension Feeders? Effects of Kelp Species, Age and Secondary Metabolites. Marine Biology, 128, 489-495. https://doi.org/10.1007/s002270050115

[31] Padilla, D.K. (1985) Structural Resistance of Algae to Herbivores. Marine Biology, 90, 103-109. https://doi.org/10.1007/BF00428220

[32] Norderhaug, K.M., Fredriksen, S. and Nygaard, K. (2003) Trophic Importance of Laminaria hyperborea to Kelp Forest Consumers and the Importance of Bacterial Degradation to Food Quality. Marine Ecology Progress Series, 255, 135-144. https://doi.org/10.3354/meps255135

[33] Duggins, D.O., Simenstad, C.A. and Estes, J.A. (1989) Magnification of Secondary Production by Kelp Detritus in Coastal Marine Ecosystems. Science, 245, 170-173. https://doi.org/10.1126/science.245.4914.170

[34] Bustamante, R.H. and Branch, G.M. (1996) The Dependence of Intertidal Consumers on Kelp-Derived Organic Matter on the West Coast of South Africa. Journal of Experimental Marine Biology and Ecology, 196, 1-28. https://doi.org/10.1016/0022-0981(95)00093-3

[35] DeNiro, M.J. and Epstein, S. (1977) Mechanism of Carbon Isotope Fractionation Associated with Lipid Synthesis. Science, 197, 261-263. https://doi.org/10.1126/science.327543

[36] Post, D.M. (2002) Using Stable Isotopes to Estimate Trophic Position: Models, Methods, and Assumptions. Ecology, 83, 703-718. https://doi.org/10.1890/0012-9658(2002)083[0703:USITET]2.0.CO;2

[37] Miller, R.J. and Page, H.M. (2012) Kelp as a Trophic Resource for Marine Suspen- 
sion Feeders: A Review of Isotope-Based Evidence. Marine Biology, 159, 1391-1402. https://doi.org/10.1007/s00227-012-1929-2

[38] Rounick, J.S. and Winterbourn, M.J. (1986) Stable Carbon Isotopes and Carbon Flow in Ecosystems. BioScience, 36, 171-177. https://doi.org/10.2307/1310304

[39] McCutchan, J.H., Lewis Jr., W.M., Kendall, C. and Mcgrath, C.C. (2003) Variation in Trophic Shift for Stable Isotope Ratios of Carbon, Nitrogen, and Sulfur. Oikos, 102, 378-390. https://doi.org/10.1034/j.1600-0706.2003.12098.x

[40] Mateo, M.A, Serrano, O., Serrano, L. and Michener, R.H. (2008) Effects of Sample Preparation on Stable Isotope Ratios of Carbon and Nitrogen in Marine Invertebrates: Implications for Food Web Studies Using Stable Isotopes. Oecologia, 157, 105-115. https://doi.org/10.1007/s00442-008-1052-8

[41] Sherman, K. and Alexander, L. (1986) Variability and Management of Large Marine Ecosystems. In: Sherman, K. and Alexander, L.M., Eds., American Association for the Advancement of Science Selected Symposium 99, Westview Press, Inc., Boulder, $\mathrm{CO}, 300$.

[42] Thomson, R.E. (1981) Oceanography of the British Columbia Coast. Department of Fisheries and Oceans Canada, Ottawa, 291 p.

[43] Shanks, A.L. and Eckert, G.L. (2005) Population Persistence of California Current Fishes and Benthic Crustaceans: A Marine Drift Paradox. Ecological Monographs, 75, 505-524. https://doi.org/10.1890/05-0309

[44] Thomson, R.E., Hickey, B.M. and LeBlond, P.H. (1989) The Vancouver Island Coastal Current: Fisheries Barrier and Conduit. Canadian Special Publication of Fisheries and Aquatic Sciences, 108, 265-296.

[45] Pearse, J.S. and Hines, A.H. (1979) Expansion of a Central California Kelp Forest Following the Mass Mortality of Sea Urchins. Marine Biology, 51, 83-91. https://doi.org/10.1007/BF00389034

[46] Estes, J.A. and Palmisano, J.F. (1974) Sea Otters: Their Role in Structuring Nearshore Communities. Science, 185, 1058-1060. https://doi.org/10.1126/science.185.4156.1058

[47] Steneck, R.S., Graham, M.H., Bourque, B.J., Corbett, D., Erlandson, J.M., Estes, J.A. and Tegner. M.J. (2002) Kelp Forest Ecosystems: Biodiversity, Stability, Resilience and Future. Environmental Conservation, 29, 436-459. https://doi.org/10.1017/S0376892902000322

[48] Cowan, I.M. and Guiguet, C.J. (1960) The Mammals of British Columbia. British Columbia Provincial Museum Handbook, No. 11.

[49] Bigg, M.A. and MacAskie, I.B. (1978) Sea Otters Reestablished in British Columbia. Journal of Mammalogy, 59, 874-876. https://doi.org/10.2307/1380163

[50] Nichol, L.M., Watson, J.C., Ellis, G.M. and Ford, J.K.B. (2005) An Assessment of Abundance and Growth of the Sea Otter Population (Enhydra lutris) in British Columbia. Fisheries and Oceans Canada, 2005/094, ii + 22, Nanaimo, B.C.

[51] Nichol, L.M., Boogaards, M.D. and Abernethy, R. (2009) Recent Trends in the Abundance and Distribution of Sea Otters (Enhydra lutris) in British Columbia. Fisheries and Oceans Canada, 3848, iv+16, Nanaimo, B.C.

[52] Markel, R.W. (2011) Rockfish Recruitment and Trophic Dynamics on the West Coast of Vancouver Island: Fishing, Ocean Climate and Sea Otters. PhD Dissertation, University of British Columbia, Vancouver.

[53] Watson, J. and Estes, J.A. (2011) Stability, Resilience, and Phase Shifts in Rocky Subtidal Communities along the West Coast of Vancouver Island, Canada. Ecolog- 
ical Monographs, 81, 215-239. https://doi.org/10.1890/10-0262.1

[54] Pickett, S.T.A. (1989) Space for Time Substitutions as an Alternative to Long-Term Studies in Ecology. In: Likens, G.E., Ed., Long-Term Studies in Ecology: Approaches and Alternatives, Springer-Verlag, New York, 110-135.

https://doi.org/10.1007/978-1-4615-7358-6_5

[55] Jacob, U., Mintenbeck, K., Brey, T., Knust, R. and Beyer, K. (2005) Stable Isotope Food Web Studies: A Case for Standardized Sample Treatment. Marine Ecology Progress Series, 287, 251-253. https://doi.org/10.3354/meps287251

[56] Fry, B. (1988) Food Web Structure on Georges Bank from Stable C, N, and S Isotopic Compositions. Limnology and Oceanography, 33, 1182-1190.

https://doi.org/10.4319/lo.1988.33.5.1182

[57] Cloern, J.E., Canuel, E.A., Harris, D. and Cloern, J.E. (2002) Stable Carbon and Nitrogen Isotope Composition of Aquatic and Terrestrial Plants of the San Francisco Bay Estuarine System. Limnology and Oceanography, 47, 713-729. https://doi.org/10.4319/lo.2002.47.3.0713

[58] Bligh, E.G. and Dyer, W.J. (1959) A Rapid Method of Total Lipid Extraction and Purification. Canadian Journal of Biochemistry and Physiology, 37, 911-917. https://doi.org/10.1139/o59-099

[59] R Development Core Team (2009) R: A Language and Environment for Statistical Computing. R Foundation for Statistical Computing, Vienna, Austria. http://www.R-project.org/

[60] Semmens, B.X. and Moore, J.W. (2008) MixSIR: A Bayesian Stable Isotope Mixing Model, Version 1.0. http://www.ecologybox.org

[61] Rubin, D.B. (1988) Using the SIR Algorithm to Simulate Posterior Distributions. In: Bernardo, J.M., Degroot, M.H., Lindley, D.V. and Smith, A.M., Eds., Bayesian Statistics 3: Proceedings of the Third Valencia International Meeting, Clarendon Press, Oxford, 385-402.

[62] Moore, J.W. and Semmens, B.X. (2008) Incorporating Uncertainty and Prior Information into Stable Isotope Mixing Models. Ecology Letters, 11, 470-480. https://doi.org/10.1111/j.1461-0248.2008.01163.x

[63] Semmens, B.X., Moore, J.W. and Ward, E.J. (2009) Improving Bayesian Isotope Mixing Models: A Response to Jackson et al. (2009). Ecology Letters, 12, E6-E8. https://doi.org/10.1111/j.1461-0248.2009.01283.x

[64] Kumagai, N.H., Molinos, J.G., Yamano, H., Takao, S., Fujii, M. and Yamanaka, Y. (2018) Ocean Currents and Herbivory Drive Macroalgae-to-Coral Community Shift under Climate Warming. Proceedings of the National Academy of Sciences of the United States of America, 115, 8990-8995. https://doi.org/10.1073/pnas.1716826115

[65] Dyer, D.C., Butler, M.J., Smit, A.J., Anderson, R.J. and Bolton, J.J. (2019) Kelp Forest POM during Upwelling and Down-Welling Conditions: Using Stable Isotopes to Differentiate between Detritus and Phytoplankton. Marine Ecology Progress Series, 619, 17-34. https://doi.org/10.3354/meps12941

[66] McConnaughey, T. and McRoy, C.P. (1979) Food-Web Structure and the Fractionation of Carbon Isotopes in the Bering Sea. Marine Biology, 53, 257-262. https://doi.org/10.1007/BF00952434

[67] Kling, G.W., Fry, B. and O’Brien, W.J. (1992) Stable Isotopes and Planktonic Trophic Structure in Arctic Lakes. Ecology, 73, 561-566. https://doi.org/10.2307/1940762

[68] Fry, B. and Wainright, S. (1991) Diatom Sources of ${ }^{13} \mathrm{C}$-Rich Carbon in Marine Food Webs. Marine Ecology Progress Series, 76, 149-157. 
https://doi.org/10.3354/meps076149

[69] Udy, J.A., Wing, S.R., O’Connell-Milne, S.A., Durante, L.M., McMullin, R.M., Kolodzey, S. and Frew, R.D. (2019) Regional Differences in Supply of Organic Matter from Kelp Forests Drive Trophodynamcis of Temperate Reef Fish. Marine Ecology Progress Series, 621, 19-32. https://doi.org/10.3354/meps12974

[70] Altabet, M.A. and Francois, R. (1994) Sedimentary Nitrogen Isotopic Ratio as a Recorder for Surface Ocean Nitrate Utilization. Global Biogeochemical Cycles, 8, 103-116. https://doi.org/10.1029/93GB03396

[71] Schell, D.M., Barnett, B.A. and Vinette, K.A. (1998) Carbon and Nitrogen Isotope Ratios in Zooplankton of the Bering, Chukchi and Beaufort Seas. Marine Ecology Progress Series, 162, 11-23. https://doi.org/10.3354/meps162011

[72] Checkley, D.M. and Miller, C.A. (1989) Nitrogen Isotope Fractionation by Oceanic Zooplankton. Deep Sea Research Part I: Oceanographic Research Papers, 36, 1449-1456. https://doi.org/10.1016/0198-0149(89)90050-2

[73] Minagawa, M. and Wada, E. (1984) Stepwise Enrichment of $\delta^{15} \mathrm{~N}$ along Food Chains: Further Evidence and the Relation between ${ }^{15} \mathrm{~N}$ and Animal Age. Geochimica et Cosmochimica Acta, 48, 1135-1140. https://doi.org/10.1016/0016-7037(84)90204-7

[74] Montoya, J.P., Carpenter, E.J. and Capone, D.G. (2002) Nitrogen Fixation and Nitrogen Isotope Abundances in Zooplankton of the Oligotrophic North Atlantic. Limnology and Oceanography, 47, 1617-1628. https://doi.org/10.4319/lo.2002.47.6.1617

[75] Lucas, M.I., Newell, R.C. and Velimirov, B. (1981) Heterotrophic Utilization of Mucilage Released during Fragmentation of Kelp (Ecklonia maxima and Laminaria pallida). II. Differential Utilization of Dissolved Organic Components from Kelp Mucilage. Marine Ecology Progress Series, 4, 43-55.

http://www.jstor.org/stable/24812959 https://doi.org/10.3354/meps004043

[76] Harris, S.L. (2001) Size-Fractionated Chlorophyll and Primary Productivity and Nutrient Distributions off the West Coast of Vancouver Island. PhD Thesis, The University of British Columbia, Vancouver.

[77] Forbes, J.R. and Denman, K.L. (1991) Distribution of Nitzschia pungens in Coastal Waters of British Columbia. Canadian Journal of Fisheries and Aquatic Sciences, 48, 960-967. https://doi.org/10.1139/f91-112

[78] Martone, R.G. and Markel, R.W. (2005) Where Is the Biomass? Variation in Subtidal Rocky Reef Community Structure Associated with the Recovery of Sea Otter Populations on the West Coast of Vancouver Island. Institute for Resources, Environment and Sustainability, University of British Columbia, Vancouver, 1-35.

[79] Raven, J.A., Johnston, A.M., Kübler, J.E., Korb, R., Mcinroy, S.G., Handley, L.L., Scrimgeour, C.M., Walker, D.I., Beardall, J., Vanderklift, M., Fredriksen, S. and Dunton, K.H. (2002) Mechanistic Interpretation of Carbon Isotope Discrimination by Marine Macroalgae and Seagrasses. Australian Journal of Plant Physiology, 29, 355-378. https://doi.org/10.1071/PP01201

[80] Westoby, M. (1978) What Are the Biological Bases of Varied Diets? The American Naturalist, 112, 627-631. https://doi.org/10.1086/283303

[81] Pennings, S.C., Nadeau, M.T. and Paul, V.J. (1993) Selectivity and Growth of the Generalist Herbivore Dolabella auricularia Feeding upon Complementary Resources. Ecology, 74, 879-890. https://doi.org/10.2307/1940813

[82] Bernays, E.A., Bright, K.L. and Gonzalez, J.A. (1994) Dietary Mixing in a Generalist 
Herbivore: Tests of Two Hypotheses. Ecology, 75, 1997-2006. https://doi.org/10.2307/1941604

[83] Kenyon, K.W. (1969) The Sea Otter in the Eastern Pacific Ocean. Bureau of Sport Fisheries and Wildlife, 68, 1-352. https://doi.org/10.3996/nafa.68.0001

[84] Estes, J.A., Jameson, R.J. and Rhode, E.B. (1982) Activity and Prey Election in the Sea Otter: Influence of Population Status on Community Structure. The American Naturalist, 120, 242-258. https://doi.org/10.1086/283985

[85] Ostfeld, R.S. (1982) Foraging Strategies and Prey Switching in the California Sea Otter. Oecologia, 53, 170-178. https://doi.org/10.1007/BF00545660

[86] Tinker, M.T., Bentall, G. and Estes, J.A. (2008) Food Limitation Leads to Behavioral Diversification and Dietary Specialization in Sea Otters. Proceedings of the National Academy of Sciences of the United States of America, 105, 560-565. https://doi.org/10.1073/pnas.0709263105

[87] DeNiro, M.J. and Epstein, S. (1978) Influence of Diet on the Distribution of Carbon Isotopes in Animals. Geochimica et Cosmochimica Acta, 42, 495-506.

https://doi.org/10.1016/0016-7037(78)90199-0

[88] Velji, M.I. and Albright, L.J. (1986) Microscopic Enumeration of Attached Marine Bacteria of Seawater, Marine Sediment, Fecal Matter, and Kelp Blade Samples Following Pyrophosphate and Ultrasound Treatments. Canadian Journal of Microbiology, 32, 121-126. https://doi.org/10.1139/m86-024

[89] Duggins, D.O. (1980) Kelp Beds and Sea Otters: An Experimental Approach. Ecology, 61, 447-453. https://doi.org/10.2307/1937405

[90] Britton-Simmons, K.H., Rhoades, A.L., Pacunski, R.E., Galloway, A.W.E., Lowe, A.T., Sosik, E.A., Dethier, M.N. and Duggins, D.O. (2012) Habitat and Bathymetry Influence the Landscape-Scale Distribution and Abundance of Drift Macrophytes and Associated Invertebrates. Limnology and Oceanography, 57, 176-184. https://doi.org/10.4319/lo.2012.57.1.0176

[91] Biber, P.D. (2007) Transport and Persistence of Drifting Macroalgae (Rhodophyta) Are Strongly Influenced by Flow Velocity and Substratum Complexity in Tropical Seagrass Habitats. Marine Ecology Progress Series, 343, 115-122. https://doi.org/10.3354/meps06893 